\title{
PERIOPERATIVE DYNAMICS OF RENAL FUNCTIONAL AND STRUCTURAL DAMAGE MARKERS IN CHILDREN, UNDERGOING OPEN HEART SURGERY
}

Summary of the Doctoral Thesis for obtaining the degree of a Doctor of Medicine Specialty - Anaesthesiology and Intensive Care 


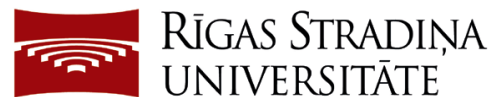

Jēkabs Krastiņš

\section{PERIOPERATIVE DYNAMICS OF RENAL FUNCTIONAL AND STRUCTURAL DAMAGE MARKERS IN CHILDREN, UNDERGOING OPEN HEART SURGERY}

Summary of the Doctoral Thesis for obtaining the degree of a Doctor of Medicine Specialty - Anaesthesiology and Intensive Care

Riga, 2019 
The Doctoral Thesis was carried out at Rīga Stradiņ̌̌ University, Children`s Clinical University Hospital, Clinics for Anesthesiology and Intensive Care, Clinic for Pediatric Cardiology and Cardiac Surgery

Scientific supervisors:

Dr. habil. med., Professor Aigars Pētersons,

Rīga Stradiņš University, Latvia

Dr. med., Professor Aivars Pētersons,

Rīga Stradiņš University, Latvia

Oficial reviewers:

Dr. med., Professor Vilnis Dzērve, University of Latvia

Dr. med., Associate Professor Harijs Čerṇevskis,

Rīga Stradiņš University, Latvia

PhD., Professor Eric Hoste, Ghent University, Belgium

Defence of the Doctoral Thesis will take place at the public session of the Doctoral Council of Medicine on 15 January 2019 at 14.00 in Hippocrates Lecture Theatre, 16 Dzirciema Street, Rīga Stradiņš University

The Doctoral Thesis is available in the RSU library and at RSU webpage: www.rsu.lv

Secretary of the Doctoral Council:

Dr. med., Associate Professor Iveta Dzīvīte-Krišāne 


\section{TABLE OF CONTENTS}

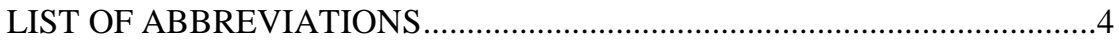

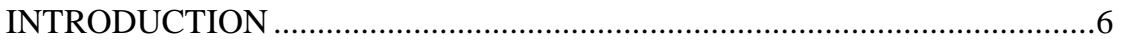

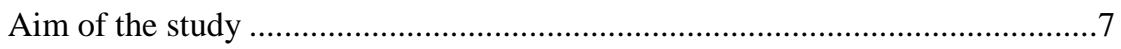

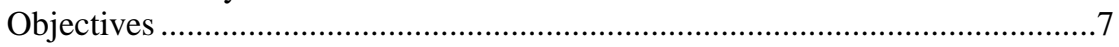

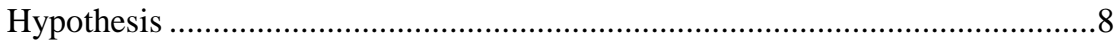

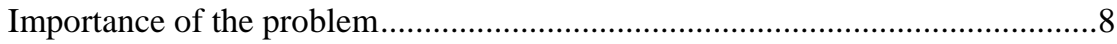

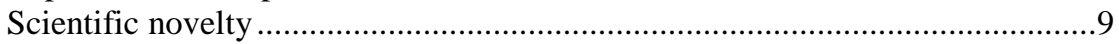

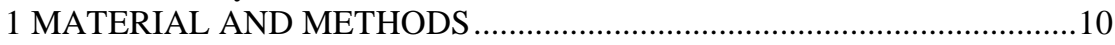

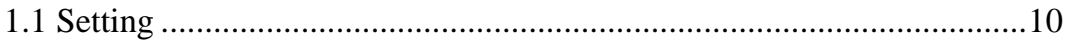

1.2 Inclusion and exclusion criteria.......................................................... 10

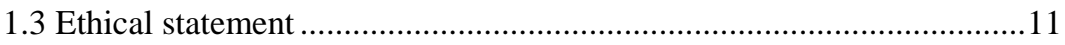

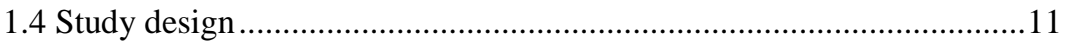

1.5 Sample collection and processing .......................................................12

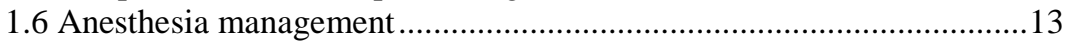

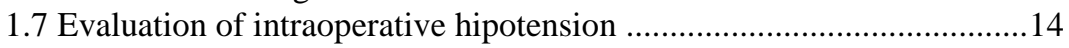

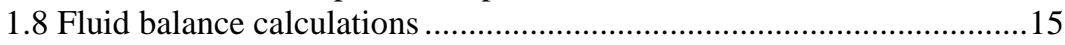

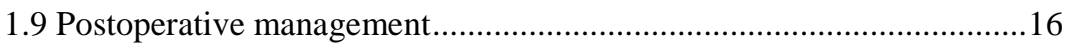

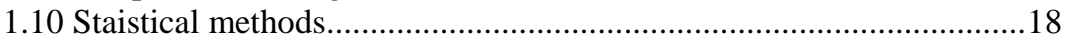

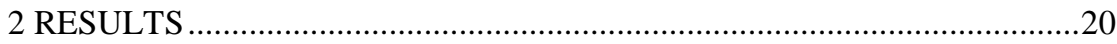

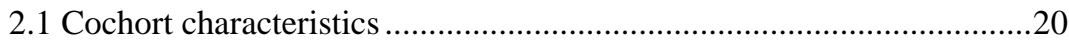

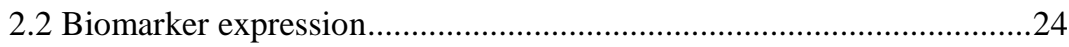

2.3 Sensitivity and specificity of various biomarkers …...........................27

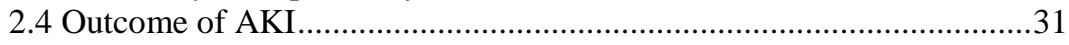

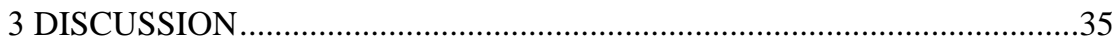

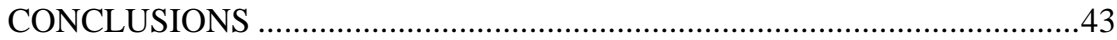

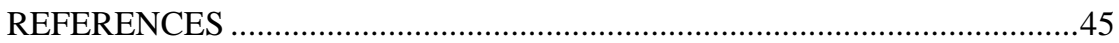

LIST OF PUBLISHED ARTICLES AND ABSTRACTS ..........................49

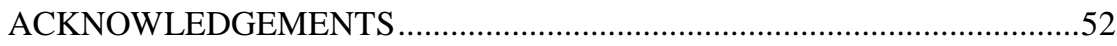




\section{LIST OF ABBREVIATIONS}

Abbreviation Explanation

ACS

Abdominal compartment syndrome

ADQI

Acute dialysis quality initiative

AKI

Acute kidney injury

AKIN

Acute kidney injury network

ARF

Acute renal failure

ATN

Acute tubular necrosis

AUC

Area under the curve

CHD

Congenital heart disease

CI

Confidence interval

$\mathrm{ClCr}$

Creatinine clearance

$\mathrm{CPB}$

Cardiopulmonary bypass

CRRT

Continous renal replacement therapy

CSA-AKI

Cardiac surgery associated AKI

CVP

Central venous pressure

Cys $\mathrm{C}$

Cystatin C

$\mathrm{eClCr}$

Estimated $\mathrm{ClCr}$

FABP

Fatty-acid-binding protein

FB

Fluid balance

$\mathrm{FeNa}$

The Fractional Excretion of Sodium

FeUrea

The Fractional Excretion of Urea

FST

Furosemide stress test

GFR

Glomerular filtration rate

GST- $\pi$

Placental glutathione S-transferase

HD

Hemodyalisis

IAH

Intraabdominal hypertension

IAP

Intraabdominal pressure

IGFPB-7

Insulin-like growth factor-binding protein 7

IHD

Intermittent hemodialysis

IL-18

Interleukin-18

IL-6

Interleukin-6

IQR

Interquartile range 
KDIGO Kidney diseases improving global outcome

KIM-1 Kidney injury molecules-1

LCOS Low cardiac output syndrome

LD Loop diuretic

LOS Lengths of stay

MAP Mean arterial pressure

MODS Multiple organ dysfunction syndrome

MV

Mechanical ventilation

NGAL Neutrophil gelatinase-associated lipocalin

OR Odds ratio

PD Peritoneal dialysis

POD Postoperative day

RACHS-1 Risk assessement for congenital heart surgery-1

RBF Renal blood flow

RIFLE

Risk, injury, failure, loss of functions, end-stage renal disease

ROC Receiver-operator curve

RRT Renal replacement therapy

$\mathrm{RVO}_{2} \quad$ Renal oxygen consumtion

$\mathrm{SCr} \quad$ Serum creatinine

SCys C Serums Cystatin C

SD Standard deviation

TBW Total body water

TIMP-2 Tissue metallopeptidase inhibitor 2

uCys C Urinary Cystatin C

UF Ultrafiltration

UMS Urine microscopy score

UNGAL Urinary NGAL

UO Urine output

VIS Vasoactive inotrope score 


\section{INTRODUCTION}

Kidneys participate in all vital processes of the body to maintain overall homeostasis. These organs receive $20 \%$ of cardiac output and are central to numerous homeostatic control mechanisms, including water balance, electrolyte handling, erythropoiesis, vascular tone, acid-base status, regulation of normal glucose metabolism and assist with detoxification and excretion of metabolites and drugs. Kidneys also moderate communication with other organs, such as heart, lung, brain, intestines and liver, and compensate the internal environment when these organs go into states of dysfunction [1]. Thus, during surgical interventions, when kidneys are injured, metabolic and hemodynamic control is disrupted. Advances in surgical techniques, medical devices, and anesthetic procedures have allowed clinicians to perform organ transplants, insert artificial devices, and conduct complex surgeries that not too long ago would have been considered high risk to perform. Now, over 200 million surgical procedures are performed worldwide. However, the number of hospitalizations that include AKI have risen to epidemic proportions, with an over eightfold increase in last decade [2]. With the central role of kidneys in precisely maintaining the internal milieu, it follows that surgeries complicated by kidney injury and dysfunction are associated with greater perioperative mortality, length of hospital stay and cost.

Pediatric patients comprise an ideal and informative population for the study of AKI biomarkers as they do not exhibit common adult confounding factors that complicate similar studies in adults, such as diabetes, hypertension, atherosclerosis, and nephrotoxin use [3]. 


\section{Aim of the study}

The aim of study was to investigate perioperative dynamics of kidney injury markers and to identify early and sensitive marker of kidney injury, suitable for application in children, undergoing open heart surgery for correction of congenital heart lesions.

\section{Objectives}

1. To establish prevalence and severity of AKI in children after open heart surgery, using KDIGO criteria.

2. To investigate the accuracy and diagnostic performance of structural and functional kidney injury markers.

3. To investigate postoperative fluid balance and it's association with renal dysfunction.

4. To evaluate the role of intraoperative hypotension in the development of postoperative AKI:

- Urinary NGAL

- Serum Cystatin C

5. To evaluate early clinical outcomes of AKI in children after open heart surgery.

6. To create an algorithm of diagnosis and management of AKI after pediatric open-heart surgery, based on postoperative fluid balance. 


\section{Hypothesis}

1. Body fluid balance can be used as a marker of postoperative renal dysfunction.

2. Systemic arterial pressure is a determinant of renal oxygen supply and intraoperative hypotension is associated with postoperative AKI.

\section{Importance of the problem}

Despite more than half a century of investigation, acute kidney injury (AKI) remains a major healthcare issue in medicine today. Furthermore, the incidence of AKI is increasing. Based on a large administrative database study of hospital admissions from 1992 to 2001, Xue et al. estimated an 11\% increase per year in the incidence of AKI [4]. Sanchez-Pinto et al. [5] have utilized a regional clinical database to investigate the link between AKI progression and death in over 8000 critically ill children over almost a decade. AKI incidence was almost $10 \%$, with 10 -fold increased mortality in patients with AKI compared with those patients with intact renal function. As expected, patients with worse AKI had greater mortality. Patients with persistent AKI throughout the PICU stay had four-fold higher mortality than patients who had resolved AKI. In fact, patients who had resolved AKI still had almost five-fold higher mortality than patients who never have had AKI. Today, postoperative renal dysfunction is becoming the next major target for investigation. Kidneys have long been thought of as a resilient organ able to endure significant stress and injury during other systemic illnesses. However, more recently we have learnt of the independent negative influence AKI has on patient outcomes [6]. In the largest cohort to date, Aydin et al. [7] demonstrated a $51 \%$ incidence of AKI, and when limiting the analysis to neonates, $60 \%$ were 
affected. Importantly, AKI was found to be independently associated with a prolonged ICU and hospital length of stay and prolonged duration of mechanical ventilation. Similar findings were reported by $\mathrm{Li}$ et al. [8] in a prospective mulitcenter study, with a $41 \%$ incidence of AKI in children undergoing CPB, which was associated with the same morbidities. Insults related to the provision of $\mathrm{CPB}$ are largely responsible for kidney injury, where the duration of bypass directly correlates with the degree of renal injury. Furthermore, despite considerable advances in diagnosis and management of severe AKI, including renal replacement therapy (RRT), mortality for this subgroup is 40-83\% [9]. These wide ranges can be explained by lack of comparability of case mix, use of different criteria for diagnosis and classification of AKI and need for RRT [10].

\section{Scientific novelty}

1. One of the first clinical studies on epidemiology and early outcome of AKI after pediatric cardiac surgery.

2. The first study, evaluating accuracy and predictive ability of renal structural and functional injury markers and investigating the impact of postoperative fluid balance on the development of AKI in children after surgical correction of congenital heart lesions. 


\section{MATERIAL AND METHODS}

\subsection{Setting}

The study was conducted in the Clinics of Anesthesiology and Intensive Care and Cardiology and Cardiac Surgery at the University Children's Clinical Hospital.

RACHS-1 consensus-based scoring system to categorize the complexity of surgery [11] was applied. This method of risk stratification has emerged as a widely accepted tool for the evaluation of differences in outcomes of surgery for congenital heart disease.

\subsection{Inclusion and exclusion criteria}

116 patients with CHD comply with inclusion criteria enrolled in the study

23 patients were excluded:

In 2 patients surgery cancelled, 2 patients died $<48$ hours (before the end of study period),

19 patients due to incomplete data

93 patients proceeded for further analysis

Fig. 1.1 Patient flow diagram 
Children undergoing elective CPB for surgical correction or palliation of congenital heart lesions between January 2011 and June 2015 were prospectively enrolled (Fig. 1.1). Exclusion criteria included preexisting renal dysfunction. Renal insufficiency was defined as a SCr level that was greater than the 90th percentile for the child's age and gender. Patients with a history of potential nephrotoxin use during the preoperative day were excluded because of potential confounding effects on urinary NGAL measurements.

\subsection{Ethical statement}

This prospective nonrandomized observational study, without any specific intervention, was reviewed and approved by University Children's Hospital Ethics board and all data were anonymously processed.

\subsection{Study design}

This was a prospective, non-randomized observational cohort study. All kidney injury markers were taken at baseline, then 12, 24 and 48 hours after completion of surgical repair (Fig. 1.2).

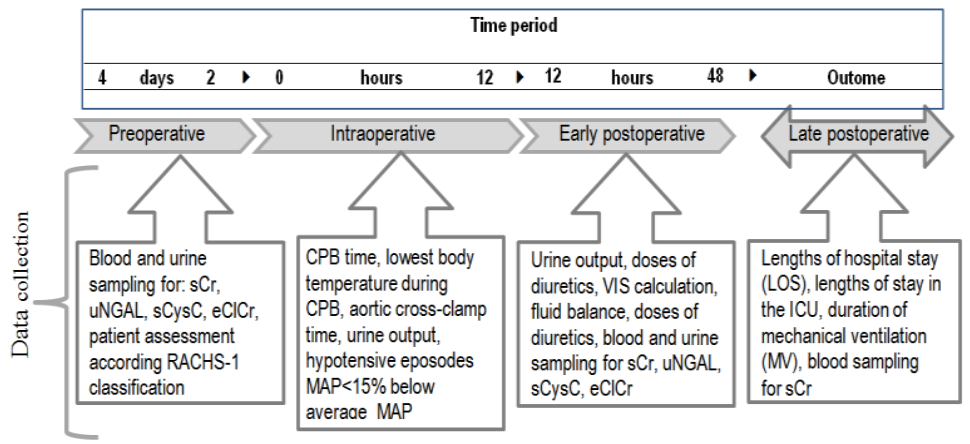

Fig. 1.2 Study design 
Other variables (CPB time, lowest body temperature, aortic cross-clamp time, urine output, duration of intraoperative hypotension, doses of diuretics, VIS calculation, fluid balance, lengths of hospital stay (LOS), lengths of stay in the ICU, duration of mechanical ventilation were retrieved from the Clinical Information system Intelly View Clinical Information Portfolio ${ }^{\circledR}$, (Philps).

\subsection{Sample collection and processing}

Creatinine concentrations were measured in the hospital's clinical chemical laboratory Jaffes method on a Cobas 8000 analyzer. SCys C was analized using particle-enhanced turbidimetric immunoassay (PETIA) for the quantitative determination, using COBAS C 501 analyzer.

Serial urine samples from 93 children undergoing CPB were assayed for uNGAL using the latest uNGAL chemiluminescent microparticle immunoassay developed for a standardized clinical platform (ARCHITECT analyzer, Abbott Diagnostics Division, Abbott Laboratories, Abbott Park, IL, USA) in the Laboratory of Renal Transplants Centre, Stradin's Clinical University Hospital. Urine samples were collected using a bladder catheter.

All samples were obtained at at the following time points: (1) preoperative; (2) 12 hours after the surgical repair, (3) 24 hours after the second probe (4) 24 hours after the third probe. Urine samples were left refrigerated for sedimentation for 2 to 3 hours, aliquoted and stored within twelve hours after collection at $-80^{\circ} \mathrm{C}$ until the assay.

The primary outcome variable was the development of AKI. AKI was defined according the KDIGO classification and staging system based on urine output and SCr level: Stage I was SCr $1.5-1.9$ times baseline $\geq 26.5 \mu \mathrm{mol} / \mathrm{L}$ increase or $\mathrm{UO}<0.5 \mathrm{~mL} / \mathrm{kg} / \mathrm{h}$ for $6-12$ hours, stage II was $\mathrm{SCr} 2-2.9$ times baseline and $\mathrm{UO}<0.5 \mathrm{~mL} / \mathrm{kg} / \mathrm{h}$ for $\geq 12$ hours, stage III was SCr 3 times baseline 
or $\geq 354 \mu \mathrm{mol} / \mathrm{L}$ and $/$ or $\mathrm{UO}<0.3 \mathrm{~mL} / \mathrm{kg} / \mathrm{h}$ for $\geq 24$ hours OR anuria for $\geq 12$ hours [12].

Recorded variables included age, gender, CPB time, lowest temperature during $\mathrm{CPB}$ and urine output, doses of diuretics, inotropes and vasopressors, postoperative fluid balance. Outcome variables included percent change in serum creatinine, days in $\mathrm{AKI}$, dialysis requirement, duration of $\mathrm{MV}$, lengths of stay in ICU and hospital LOS.

\subsection{Anesthesia management}

Induction to anesthesia was provided using inhalation of Sevoflurane by face mask or intravenously by Propofol or Midazolam in combination with Ketamine. Anesthesia was maintained at (0.8-1.0 minimal alveolar concentration) of sevoflurane and fentanyl ( $3-5 \mu \mathrm{g} \mathrm{kg} / \mathrm{h})$ using Primus anesthesia machine (Drãger Medical, Lübeck, Germany). Muscle relaxation was achieved with pipecuronium $(0.6 \mathrm{mg} / \mathrm{kg})$. During $\mathrm{CPB}$, isoflurane was applied via the $\mathrm{CPB}$ circuit. All patients were ventilated in a volume-controlled mode; with a tidal volume of $6 \mathrm{~mL} / \mathrm{kg}$ and respiratory rate adjusted to achieve normocapnia. The heart-lung machine SORIN S 5 (LivaNova, United Kingdom) with a membrane oxygenator Affinity Pixie ${ }^{\circledR}$ Oxygenatior (Medrtronics, USA) for neonates, infants and small children requiring cardiopulmonary bypass at flow rates up to 2.0 L/min. was used. For older patients Terumo, Medtronic $\mathrm{C}$ oxygenator with CPB circuit was used. Surgical procedures were performed with CPB in moderate hypothermia. Cardioplegic arrest was achieved by cold blood cardioplegia and repeated every 20 minutes. Nonpulsatile perfusion was performed during CPB. Pump flow, oxygen flow, and MAP were adjusted to maintain $\mathrm{ScvO}_{2}$ levels within the preoperative range and at least higher than $50 \%$ absolute. In patients monitored with pulmonary artery catheter (PAC), 
hemodynamic therapy was titrated to achieve cardiac index $>2.2 \mathrm{~L} / \mathrm{min} / \mathrm{m}^{2}$ and mixed venous oxygen saturation $\left(\mathrm{Sv} \mathrm{O}_{2}\right)$ greater than $65 \%$.

Fluid therapy was performed with balanced crystalloid (Lactated Ringers solution, Sterofundin VG, BBraun; Melsungen, Germany). Pump prime consisted of various amounts of Ringer lactate and whole blood, depending on estimated blood volume, hematocrit, and total priming volume used. Hypothermic myocardial protection was provided by core cooling at flow rates of 150 to $200 \mathrm{~mL} / \mathrm{kg} / \mathrm{min}$. (2.0 to $3.0 \mathrm{~kg}$ ) or 100 to $150 \mathrm{~mL} / \mathrm{kg} / \mathrm{min}$. (3.0 to $5.0 \mathrm{~kg}$ ) to rectal and esophageal temperatures of $\leq 30^{\circ} \mathrm{C}$, followed by aortic cross clamping. Once optimal hypothermic temperatures were reached, continuous low-flow cardiopulmonary bypass was instituted during completion of intracardiac stage. Core rewarming was instituted during completion of the intracardial stage. Mean perfusion pressures were maintained between $30 \mathrm{~mm}$ $\mathrm{Hg}$ and $70 \mathrm{~mm} \mathrm{Hg}$ during rewarming. All patients were weaned from cardiopulmonary bypass after the rectal temperature reached $35^{\circ} \mathrm{C}$. Lactated Ringers, fresh whole blood, blood products, and increased inotropic support were given as necessary to maintain normal filling pressures and a systolic perfusion pressure of at least $60 \mathrm{~mm} \mathrm{Hg}$.

\subsection{Evaluation of intraoperative hypotension}

Blood pressure in all patients was measured by means of an intra-arterial (radial or femoral) line (systolic, diastolic and mean) with Philips Vital signs monitor and stored automatically every 5 minutes $(300 \mathrm{sec}$. or 12 times during one hour) in the patient data management system (Philips IntelliView Clinical Information Portfolio, ICIP). 


\begin{tabular}{|c|c|c|c|c|c|c|c|c|c|c|c|}
\hline \multirow{2}{*}{$\begin{array}{l}\text { ums Formas/kontrolsaraksti } \\
\text { ärskata tabula (OR) }\end{array}$} & \multicolumn{2}{|c|}{ Ordinscijas [ Plezmes] Parskats } & \multicolumn{3}{|c|}{ Laboratorijas dati Irakistilanas dokumenti } & \multicolumn{6}{|c|}{ Ov Darba mape } \\
\hline & $\begin{array}{l}\text { 1/11/2017 } \\
11: 15 \text { AM }\end{array}$ & $11: 20$ AM & $11: 25 \mathrm{AM}$ & $11: 30 \mathrm{AM}$ & $11: 35 \mathrm{AM}$ & $11: 40 \mathrm{AM}$ & $11: 45$ AM & 11:50 AM & $11: 55 \mathrm{AM}$ & $12: 00 \mathrm{FM}$ & Op \\
\hline \multicolumn{11}{|l|}{ Sagatavodanas laks } & \\
\hline \multicolumn{11}{|l|}{ Aprüpes laks cperäciju zals } & \\
\hline \multicolumn{11}{|l|}{ Anestêzijas laks } & \\
\hline \multicolumn{11}{|l|}{ Anes, sak/beidz } & \\
\hline \multicolumn{12}{|l|}{ Anes, ilgums } \\
\hline \multicolumn{12}{|l|}{ Kermena masa (Kg) (Daily) } \\
\hline Arterialais asmsspiediens & $100 / 53(73)$ & $98 / 50(71)$ & $101 / 50(73)$ & $96 / 52(71)$ & $75 / 43(55)$ & $77 / 46(58)$ & $71 / 43(54)$ & $68 / 41(51)$ & $68 / 41(51)$ & $64 / 41(50)$ & $\leqslant$ \\
\hline Neinvazlvais asinsspiediens & $100 / 65(72)$ & & & $73 / 40(46)$ & & & $58 / 39(44)$ & & & $63 / 36(41)$ & \\
\hline Sirdsdarbbas frekvence & 98 & 97 & 99 & 110 & 107 & 120 & 122 & 117 & 133 & 139 & \\
\hline spor & 100 & 100 & 100 & 100 & 100 & 100 & 99 & 100 & 100 & 100 & \\
\hline Epolanas frekvence & 28 & 28 & 30 & 46 & 67 & 38 & 26 & 22 & 25 & 31 & \\
\hline Temperatüra (C) & 37.0 & 37.1 & 37.2 & 37.3 & 37.5 & 37.6 & 37.8 & 38.0 & 38.2 & 38.5 & \\
\hline Temperatōra (C) Skn & 35.5 & 35.4 & 35.7 & 36.2 & 36.7 & 37.1 & 37.5 & 37.8 & 38.2 & 38.4 & \\
\hline Temperatöra (C) Core & 37.0 & 37.1 & 37.2 & 37.3 & 37.5 & 37.6 & 37.8 & 38.0 & 38.2 & 38.5 & \\
\hline Sirds ritms & & & & & & & & & & & \\
\hline
\end{tabular}

Fig. 1.3 Screenshot from anesthesia flowchart, generated by IntelliView Clinical Information Portfolio ${ }^{\circledR}$ (Philips)

Systolic, diastolic and mean arterial pressure recordings during anesthesia (Indicated by arrow)

MAP data were extracted from anesthesia charts and transfered to MS Excell spredsheets for further processing. Then an average of all validated MAP recordings was calculated for each patient. Hypotension was defined as a MAP $<15 \%$ less than averagee MAP value. Then all MAP recordings were compared to average (except MAP recordings during CPB, when pulsatile blood flow was absent). Ratio of hypotensive MAP recordings (MAP $<15 \%$ less than averagee MAP value) to total MAP recordings was calculated and expressed as $\%$. Artefacts (arterial cannulae flushing, sensor calibration etc. were marked by operator).

\subsection{Fluid balance calculations}

Intraoperative fluid intake was assessed by totaling the intravenous fluids, cardioplegia volume, and pump volume (total volume added during cardiopulmonary bypass plus reservoir volume at the start of cardiopulmonary bypass minus reservoir volume at the termination of cardio-pulmonary bypass). 


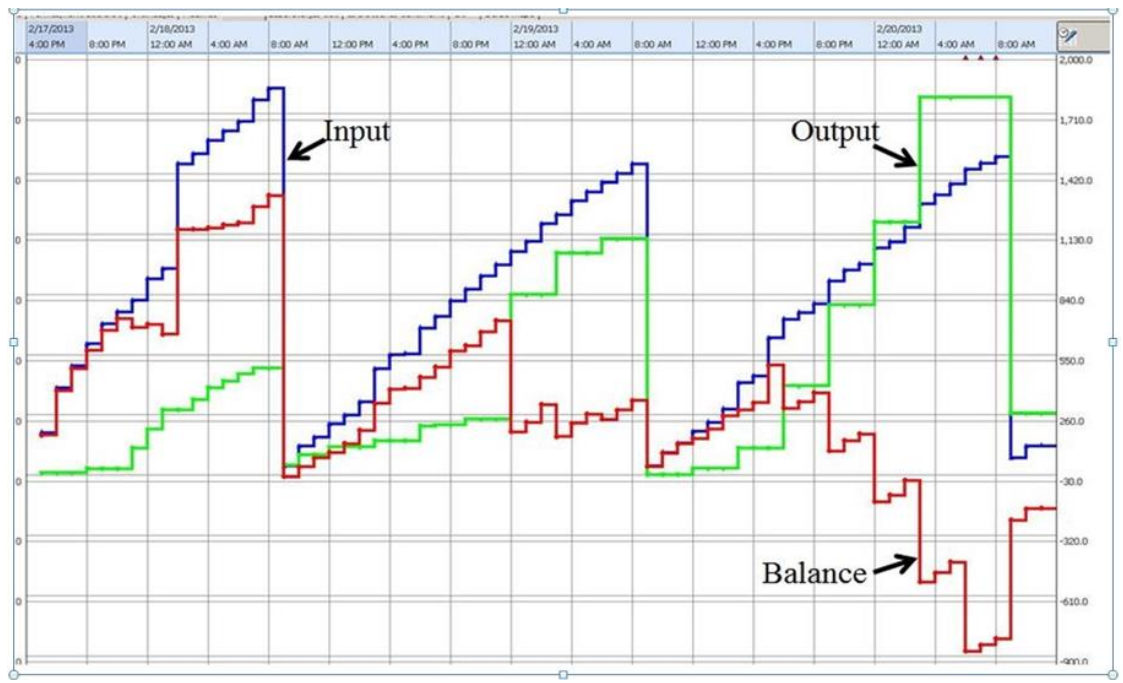

Fig. 1.4 Postoperative fluid balance

Screenshot from IntelliView Clinical Information Portfolio ${ }^{\circledR}$ (Philips)

Fluid balance calculations Intraoperative fluid output was the total of urine produced on cardiopulmonary bypass, chest tube drainage before the patient left the operating room, and estimated blood loss. Intraoperative net fluid balance was the difference between fluid intake and output. Data for further processing were retrieved from anesthesia and intensive care data management system flowsheets (Fig. 1.4). Similarly, fluid balance was calculated after the completion of surgical repair. Patient data were collected from day of admission to Intensive care (denoted as POD-1).

\subsection{Postoperative management}

Analgesia and sedation were provided by a continuous fentanyl or morphine infusion, typically 2-4 $\mu \mathrm{g} \times \mathrm{kg}^{-1} \times \mathrm{h}^{-1}$ and Midazolam or Dexmedetomidine. Routine continuous postoperative monitoring included the surface ECG, transcutaneous pulse oximetry, pulmonary arterial and right and left atrial 
pressures (through transthoracic catheters), and systemic arterial pressure. Inotropic, chronotropic, and afterload reducing agents were used as clinically indicated. Vasoactive medications are typically started in the operating room at the discretion of the attending cardiac surgeon and anesthesiologist based on individual patient characteristics, including, residual lesions, transesophageal echocardiographic findings, and physiological status. On arrival to the ICU, medications are adjusted by the bedside nurse under the direction of the ICU team. Patients with hypotension typically receive norepinephrine and epinephrine initially, Volume infusions (Plasma or 5\% albumin) were given to maintain adequate filling pressures with systolic perfusion pressures of at least $50 \mathrm{~mm} \mathrm{Hg}$. Diuretics (usually furosemide 1 to $2 \mathrm{mg} / \mathrm{kg}$ per dose, two to four times daily) were prescribed at the attending physician's discretion if a targeted fluid balance or urine output of $>0.5 \mathrm{~mL} / \mathrm{kg} /$ hour could not be achieved. Some patients received continuous infusion of Furosemide and Aminophilline.During the study continuous fentanyl or morphine infusions were discontinued on the first postoperative morning in the hemodynamically stable patient or continued for longer periods as dictated by the clinical status of the patient. Mechanic ventilation was provided with Viasys Avea ventilator (Cardinal Health, USA). At the mode suitable for specific cardiac lesion. The rate of weaning of mechanical ventilation was determined by the patient's fluid balance and gas exchange as indicated by arterial blood sampling, pattern of breathing, and daily radiographic findings. VIS score was calculated according the formula [13]:

VIS $=1$ dopamine $(\mu \mathrm{g} / \mathrm{kg}$ per minute $)+1$ dobutamine $(\mu \mathrm{g} / \mathrm{kg}$ per minute $)+$ 10 milrinone $(\mu \mathrm{g} / \mathrm{kg}$ per minute $)+100$ epinephrine $(\mu \mathrm{g} / \mathrm{kg}$ per minute $)+$ 100 norepinephrine $(\mu \mathrm{g} / \mathrm{kg}$ per minute $)+1000$ vasopressin (expressed as $\mathrm{U} / \mathrm{kg}$ per minute).

The initial mode of ventilation was pressure-regulated volume control in all patients. Once the patient was breathing spontaneously and ready for weaning, 
the ventilator mode was switched to pressure-controlled, synchronized, intermittent, mandatory ventilation.

The criteria for extubation was protocolized, as follows: stable hemodynamic profile, normal cardiac rhythm, adequate oxygenation on fraction of inspired oxygen $<0.4$, maintenance of a $\mathrm{pH}>7.35$, and $\mathrm{PacCO}_{2}<45 \mathrm{~mm} \mathrm{Hg}$ on continuous positive airway pressure $<6 \mathrm{~cm} \mathrm{H} \mathrm{H}_{2} \mathrm{O}$ with pressure support $<8 \mathrm{~cm} \mathrm{H}_{2} \mathrm{O}$ for at least $1 \mathrm{~h}$, the level of consciousness consistent with adequate airway protective reflexes, absence of accessory respiratory muscle recruitment, and approval by the attending intensivists. Corticosteroids were routinely administrated 4 to $6 \mathrm{~h}$ before extubation. All patients were monitored with invasive arterial and central blood pressure monitoring. In patients undergoing complex cardiac surgery left atrial or pulmonary artery catheter was inserted during surgical repair. Transesophageal echocardiography was performed in all valve surgery cases. Cerebral oxygen saturation $\left(\mathrm{ScO}_{2}\right)$ was determined in all patients with an INVOS 5100 monitor (Somanetics, Troy, USA). All patients received routine standard of care during the study period which included the use of dextrose-containing crystalloid solutions (Sterofundin HEG, Sterofundin BG, Sterofundin VG (BBraun, Melsungen, $50-80 \mathrm{~mL} / \mathrm{kg} / \mathrm{day}$ ) during the first 24-48 hours postoperatively, followed by the initiation of enteral tube feeding.

\subsection{Staistical methods}

Unless indicated otherwise, continuous data are expressed as median values with interquartile range (IQR) and discrete data as numbers with percentages (\%). Patients were grouped according to whether they lacked AKI or had AKI within 48 hours following CPB. Clinical characteristics and biomarker levels were compared between AKI- and non-AKI patients using Student's t test for normally distributed continuous variables, Mann-Whitney 
$\mathrm{U}$ test was performed for non-normally distributed continuous variables and Pearson's $\chi^{2}$ or Fisher's exact test, (as appropriate) was performed on all categorical variables. Statistical significance was defined as a probability value less than 0.05 .

Univariate logistic analysis was performed to examine the relationship between multiple clinical variables as well as the presence of AKI and clinical outcomes (ICU length of stay, hospital length of stay, duration of mechanical ventilation, and in-hospital mortality). Variables with a probability value less than 0.1 were then cast into a multivariate logistic regression analysis. Odds ratio, CI, and probability values were calculated. All univariate and multivariate logistic regression analyses were conducted for the entire cohort. Receiver operating characteristics (ROC) curves were generated for the occurrence of AKI within 48 hours following cardiopulmaonary bypass using biomarker levels at four different time points (baseline, 12 hours, 24 hours and 48 hours). The areas under the curve (AUC), with $95 \%$ confidence intervals $(95 \% \mathrm{CI})$, were calculated. Also, for each time point the optimal cut-of value was calculated with corresponding sensitivity and specificity. Using those cut-of values, sensitivity and specificity of both biomarkers for predicting AKI were calculated for patients who developed AKI. Two-sided $p=0.05$ was considered the limit of significance in all analyses. Data were analyzed using IBM SPSS statistics version 21 (Statistical Package for the Social Sciences, Chicago, IL). 


\section{RESULTS}

\subsection{Cochort characteristics}

Majority from 93 included patients 54 (58\%) were less than 12 months old, 6 patients $(6.45 \%)$ were less than 1 months old, 20 (21.51\%) patients were between 1 and 6 months of age; patients at age of 7 to 12 months were $28(30.11 \%)$. Age group of 1 to 3 years represents 23 (24.73\%) children.

Table 2.1

Age structure

\begin{tabular}{|l|c|c|}
\hline \multicolumn{1}{|c|}{ Age group } & No of pts & $(\%)$ \\
\hline Less than 1 month & 6 & 6.45 \\
\hline $1<6$ months & 20 & 21.51 \\
\hline $7<12$ months & 28 & 30.11 \\
\hline $1<3$ years & 23 & 24.73 \\
\hline $3<7$ years & 6 & 6.45 \\
\hline 7 years and older & 10 & 10.75 \\
\hline Total: & 93 & 100.00 \\
\hline
\end{tabular}

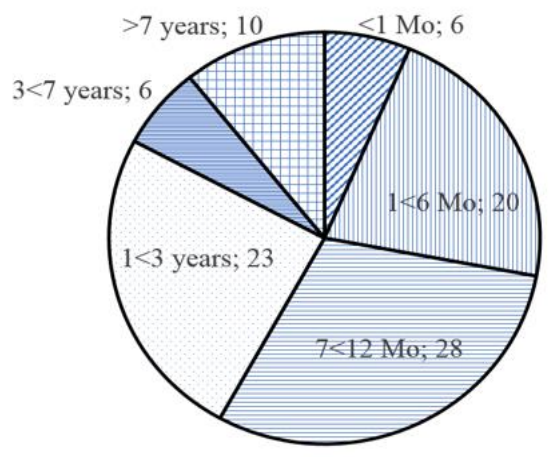

Fig. 2.1 Age distribution of patients 
Demographic data

\begin{tabular}{|l|c|c|c|}
\hline \multicolumn{1}{|c|}{ Variable } & Median & IQR $(\mathrm{Q} 1-\mathrm{Q} 3)$ & Range \\
\hline Age, months & 10.0 & $6.0-17$ & $0.2-180.0$ \\
\hline Body weight $(\mathrm{kg})$ & 7.6 & $5.6-10$ & $2.6-60.0$ \\
\hline M/F ratio: & $35 / 58$ & - & - \\
\hline
\end{tabular}

Types of congenital heart lesions undergoing surgical repair are summarized in Table 2.3:

Table 2.3

\section{Types of surgical intervention}

\begin{tabular}{|l|c|c|}
\hline \multicolumn{1}{|c|}{ Surgical intervention } & No of pts & $\%$ \\
\hline AVSD (atrioventricular septal defect) repair & 20 & 21.51 \\
\hline Double outlet right ventricle (DORV) & 3 & 3.23 \\
\hline Pulmonary stenosis repair & 5 & 5.38 \\
\hline Tricuspid regurgitation repair & 2 & 2.15 \\
\hline Unifocalization procedure & 2 & 2.15 \\
\hline Aortic stenosis repair & 3 & 3.23 \\
\hline VSD (ventricular septal defect) repair & 37 & 39.78 \\
\hline Mitral valve plastics & 2 & 2.15 \\
\hline TAPVD (total anomalous pulmonary vein drainage) & 4 & 4.30 \\
\hline TGA (transposition of great arteries) & 6 & 6.45 \\
\hline TOF (tetralogy of Fallot) & 9 & 9.68 \\
\hline \multicolumn{1}{|c|}{ Total: } & 93 & 100.00
\end{tabular}

Postoperative AKI occurred in 42 (45.16\%) from 93 children. 37 of them reached severity stage I according the KDIGO classification and stating system, 3 reached stage II and two reached stage III, based on SCr and (or) urine output criteria (Fig. 2.2). 


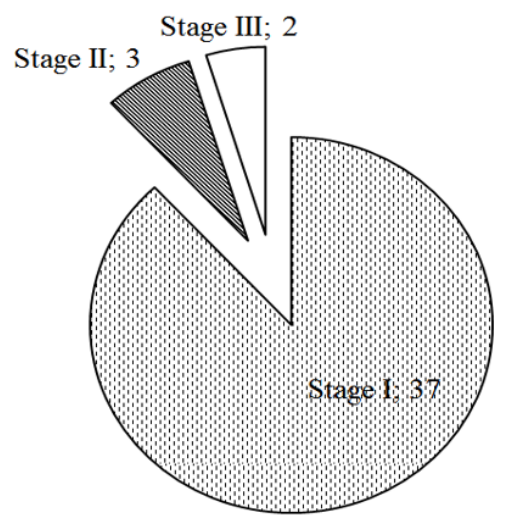

Fig. 2.2 Severity of AKI

Fig. 2.3 shows changes in $\%$ from the baseline $\mathrm{SCr}$ concentration to maximum during 48 hours. It represents number of patients for each AKI severity stage.

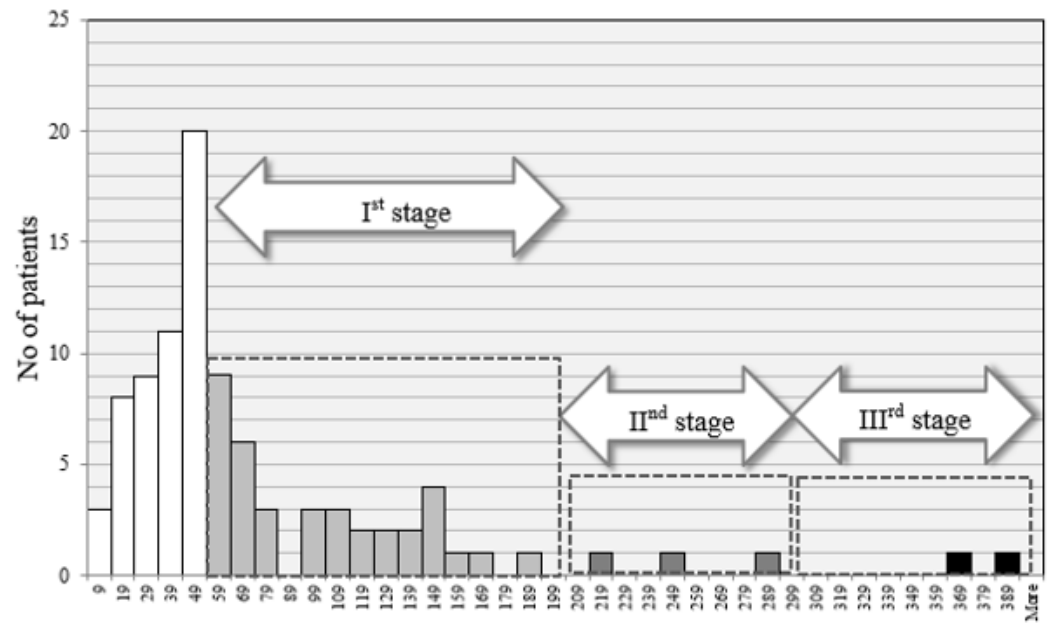

Fig. 2.3 Histogram of $\Delta \mathrm{SCr}$ 
Table 2.4 shows the characteristics in patients with and without postoperative AKI, as asseded by univariated analysis. Those with AKI were younger (12.5 months in non-AKI group versus 8.0 months in AKI group, $\mathrm{p}=0.014)$ and having less body weight $(7.0 \mathrm{~kg}$ versus $8.0 \mathrm{~kg}$ in AKI group, $\mathrm{p}=0.026$ ). Male gender dominates in the AKI group $69.04 \%$ versus $56.86 \%$, but the difference was not statistically significant $(\mathrm{p}=0.39)$. There was no difference in aortic cross-clamp time, body temperature during cooling, urine output, and the proportion of patients having cyanotic lesions. CPB time, diuretic doses, GFR, VIS and RACHS-1 scores differs significantly in AKI and non-AKI groups (Table 2.4).

Postoperative reduction of GFR differs in AKI and non-AKI group: $\mathrm{eClCr}$ in non-AKI group was 106.48 (IQR $86.26-127.09$ ) $\mathrm{mL} / \mathrm{min} / 1.73 \mathrm{~m}^{2}$ versus 61.57 (IQR 44.91-89.85) $\mathrm{mL} / \mathrm{min} / 1.73 \mathrm{~m}^{2}$ in AKI group, $\mathrm{p}=0.0001$ (Table 2.4).

Median doses of furosemide used for patients in AKI group was higher $(2.68 \mathrm{mg} / \mathrm{kg} / \mathrm{h}$ ) versus $1.63 \mathrm{mg} / \mathrm{kg} / \mathrm{h}$ in non-AKI group, $\mathrm{p}=0.024$ (Table 2.4). Number of patients having cyanotic lesions was 9 from 51 (17.64\%) in non-AKI group versus 14 from 42 (33.33\%) in AKI group, but the difference was not statistically significant (Table 2.4).

Table 2.4

Characteristics of study cochort by AKI status

\begin{tabular}{|l|c|c|c|c|}
\hline $\begin{array}{c}\text { Variable } \\
(\text { Median, IQR) }\end{array}$ & All & Non-AKI & AKI & p value \\
\hline Gender male & $58 / 93(62.36 \%)$ & $29 / 51(56.86)$ & $29 / 42(69.04 \%)$ & $0.39^{\#}$ \\
\hline Age, months & $\begin{array}{c}10.00 \\
(6.00-17.00)\end{array}$ & $\begin{array}{c}12.50 \\
(7.00-25.75)\end{array}$ & $\begin{array}{c}8.0 \\
(3.00-13.00)\end{array}$ & $0.0014^{*}$ \\
\hline $\begin{array}{l}\text { Age < 12 } \\
\text { months }\end{array}$ & $52 / 93(55.91 \%)$ & $26 / 51(50.98 \%)$ & $30 / 42(71.42 \%)$ & $0.056^{\#}$ \\
\hline Body weight, $\mathrm{kg}$ & $7.60(5.60-10.00)$ & $8.00(6.73-11.63)$ & $7.00(4.28-8.33)$ & $0.026^{*}$ \\
\hline $\begin{array}{l}\text { Body weight }<8 \\
\text { kg }\end{array}$ & $52 / 93(55.91 \%)$ & $23 / 51(45.09 \%)$ & $29 / 42(69.04 \%)$ & $0.023^{\#}$ \\
\hline
\end{tabular}


Table 2.4 continued

\begin{tabular}{|l|c|c|c|c|}
\hline $\begin{array}{c}\text { Variable } \\
\text { (Median, IQR) }\end{array}$ & All & Non-AKI & AKI & p value \\
\hline CPB time (min.) & $\begin{array}{c}156.00 \\
(58.00-560.00)\end{array}$ & $\begin{array}{c}86.00 \\
(30.00-116.00)\end{array}$ & $\begin{array}{c}166.00 \\
(146.60-231.50)\end{array}$ & $0.0024^{*}$ \\
\hline $\begin{array}{l}\text { Aortic cross- } \\
\text { clamping time } \\
\text { (min.) }\end{array}$ & $\begin{array}{c}99.00 \\
(64.75-126.50)\end{array}$ & $\begin{array}{c}90.00 \\
(60.00-120.00)\end{array}$ & $\begin{array}{c}107.00 \\
(81.75-128.75)\end{array}$ & $0.44^{*}$ \\
\hline $\begin{array}{l}\text { Lowest body } \\
\text { temperature (C) }\end{array}$ & $\begin{array}{c}30.00 \\
(28.00-31.92)\end{array}$ & $\begin{array}{c}30.45 \\
(26.18-32.00)\end{array}$ & $\begin{array}{c}30.00 \\
(27.63-31.50)\end{array}$ & $0.303^{*}$ \\
\hline $\begin{array}{l}\text { Urine output } \\
\text { (mL/kg/h) }\end{array}$ & $2.28(1.28-2.82)$ & $2.26(1.57-2.92)$ & $1.90(0.98-2.47)$ & $0.083^{*}$ \\
\hline $\begin{array}{l}\text { RACHS-1 } \\
\text { category }\end{array}$ & $3(2-3)$ & $2(2-3)$ & $3(2-3)$ & $0.0098^{*}$ \\
\hline $\begin{array}{l}\text { RACHS-1 } \\
\text { category } \geq 3\end{array}$ & $44 / 93(25.80 \%)$ & $18 / 51(35.29 \%)$ & $26 / 42(61.90 \%)$ & $0.0129^{\#}$ \\
\hline VIS score & $6(5-7)$ & $5(5-6)$ & $7(6-10)$ & $0.0098^{*}$ \\
\hline $\begin{array}{l}\text { Cyanotic lesions } \\
\text { \%) }\end{array}$ & $23 / 93(24.73 \%)$ & $9 / 51(17.64 \%)$ & $14 / 42(33.33 \%)$ & $0.15^{\#}$ \\
\hline $\begin{array}{l}\text { Dose of } \\
\text { furosemide } \\
\text { (mg/kg/day) }\end{array}$ & $2.04(1.02-3.11)$ & $1.63(1.02-3.11)$ & $2.68(1.84-4.85)$ & $0.024^{*}$ \\
\hline $\begin{array}{l}\text { Postoperative } \\
\text { eClCr } \\
\text { mL/min/1.73 } \mathrm{m}^{2}\end{array}$ & $(50.37-106.48)$ & $(86.26-127.09)$ & $(44.91-89.85)$ & $0.0001^{*}$ \\
\hline
\end{tabular}

"Fisher's exact test * Mann-Whitney U Test

\subsection{Biomarker expression}

Concentration of SCys C rise at 12 hours from surgery from $0.86 \mathrm{mg} / \mathrm{L}$ $(0.73-0.92)$ to $1.06 \mathrm{mg} / \mathrm{L}(0.83-1.37)$ in AKI group. In the non-AKI group SCys C incteases to $0.82 \mathrm{mg} / \mathrm{L}$. (0.68-0.98). Maximum expression of SCys C was observed at 24 hours after the surgery. 
In the AKI group SCys C level was $1.31 \mathrm{mg} / \mathrm{L}$ (1.06-1.48) versus 0.77 $\mathrm{mg} / \mathrm{L}(0.63-1.06)$ in non-AKI group. The rise from the baseline value was statistically significant $(\mathrm{p}=0.003)$. Then, after 48 hours biomarker level returns to baseline (Fig. 2.4, Table 2.5). Concentration of uNGAL has the maximum expression at 12 hours after surgery. It rises from $7.05 \mathrm{ng} / \mathrm{mL}(2.7-12.13)$ to $132.85 \mathrm{ng} / \mathrm{mL}$ (60.78-257.23), reching a peak level of $1680 \mathrm{ng} / \mathrm{mL}$ in AKI group.

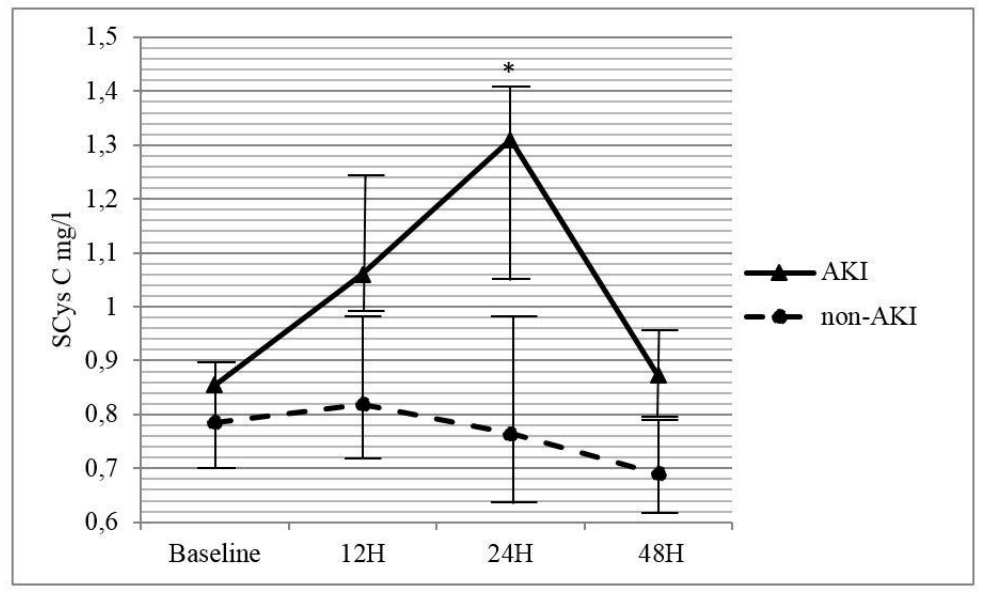

Figure 2.4 Postoperative dynamics of SCys C

Serum Cystatin $\mathrm{C}(\mathrm{sCysC})$ concentrations measured at intervals at baseline and at 12 , 24, and $48 \mathrm{hr}$ after CPB in patients with (continuous line) or without (dashed line) acute kidney injury (AKI). Median and interquartile range (IQR) are presented.

In the probe taken at 24 hours expression of UNGAL gradually decreases to $36.60 \mathrm{ng} / \mathrm{mL}$ in AKI group and $13.40 \mathrm{ng} / \mathrm{mL}$ in non-AKI group. At 48 hours uNGAL level returns to baseline: $7.40 \mathrm{ng} / \mathrm{mL}(4.00-23.20)$ in AKI group and $4.80 \mathrm{ng} / \mathrm{mL}$ (2.20-15.00) in non-AKI group (Fig. 2.5, Table 2.5). 


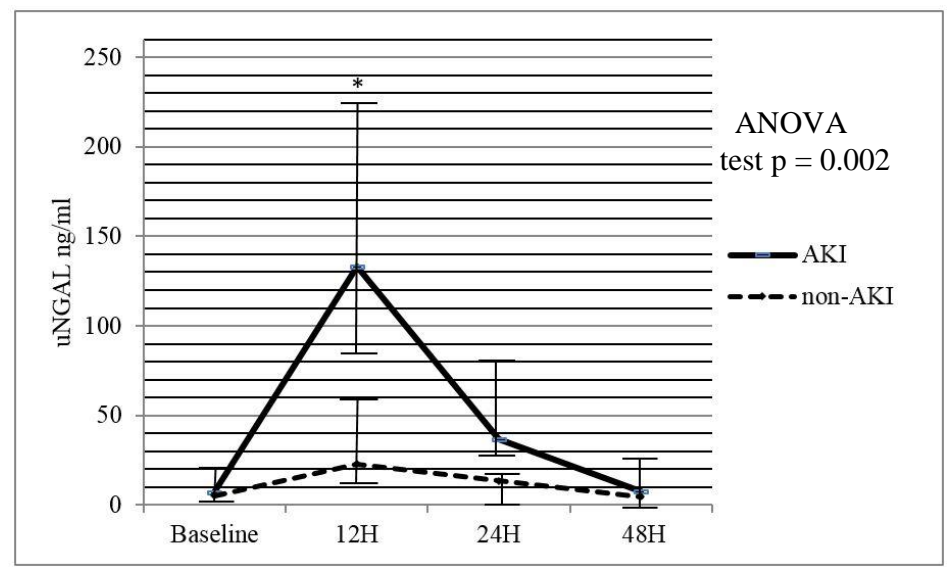

Figure 2.5 Postoperative dynamics of uNGAL

Urine neutrophil gelatinase-associated lipocalin (uNGAL) concentrations measured at intervals at baseline and at 12,24, and $48 \mathrm{hr}$ after CPB in patients with (continuous line) or without (dashed line) acute kidney injury (AKI). Median and interquartile range (IQR) are presented.

Table 2.5

Dinamics of perioperative expression of SCys C and UNGAL

\begin{tabular}{|c|c|c|c|c|c|}
\hline Categ. & Biomarker & Baseline & $12 \mathrm{H}$ & $24 \mathrm{H}$ & $48 \mathrm{H}$ \\
\hline AKI & $\begin{array}{c}\begin{array}{l}\text { SCys C } \\
(\mathrm{mg} / \mathrm{L})\end{array} \\
\text { Median (Q1- } \\
\text { Q3) [Range] } \\
\end{array}$ & $\begin{array}{c}0.86 \\
(0.73-0.92) \\
{[0.57-1.20]}\end{array}$ & $\begin{array}{c}1.06 \\
(0.83-1.37) \\
{[0.60-2.44]}\end{array}$ & $\begin{array}{c}1.31 \\
(1.06-1.48) \\
{[0.69-2.95]}\end{array}$ & $\begin{array}{c}0.87 \\
(0.78-1.10) \\
{[0.59-1.92]}\end{array}$ \\
\hline $\begin{array}{l}\text { Non- } \\
\text { AKI }\end{array}$ & $\begin{array}{c}\text { SCys C } \\
(\mathrm{mg} / \mathrm{L}) \\
\text { Median (Q1- } \\
\text { Q3) [Range] }\end{array}$ & $\begin{array}{c}0.79 \\
(0.72-0.89) \\
{[0.55-0.99]}\end{array}$ & $\begin{array}{c}0.82 \\
(0.68-0.98) \\
{[0.48-1.98]}\end{array}$ & $\begin{array}{c}0.77 \\
(0.63-1.06) \\
{[0.45-1.65]}\end{array}$ & $\begin{array}{c}0.69 \\
(0.66-0.82) \\
{[0.47-1.61]}\end{array}$ \\
\hline AKI & $\begin{array}{c}\text { uNGAL ng/mL } \\
\text { Median (Q1- } \\
\text { Q3) [Range] }\end{array}$ & $\begin{array}{c}7.05 \\
(2.7-12.13) \\
{[0.6-49.26]}\end{array}$ & $\begin{array}{c}132.85 \\
(60.78-257.23) \\
{[8.70-1680]} \\
\end{array}$ & $\begin{array}{c}36.60 \\
(7.3-74.68) \\
{[1.30-980.001]}\end{array}$ & $\begin{array}{c}7.40 \\
(4.00-23.20) \\
{[0.4-863.00]} \\
\end{array}$ \\
\hline $\begin{array}{l}\text { Non- } \\
\text { ANB }\end{array}$ & $\begin{array}{l}\text { uNGAL ng/mL } \\
\text { Median (Q1- } \\
\text { Q3) [Range] }\end{array}$ & $\begin{array}{c}5.35 \\
(2.25-7.75) \\
{[0.40-62.25]}\end{array}$ & $\begin{array}{c}22.90 \\
(12.3-75.65) \\
{[1.20-451.00]}\end{array}$ & $\begin{array}{c}13.40 \\
(6.73-19.6) \\
{[1.20-203.90]}\end{array}$ & $\begin{array}{c}4.80 \\
(2.20-15.00) \\
{[0-124.50]}\end{array}$ \\
\hline
\end{tabular}




\subsection{Sensitivity and specificity of various biomarkers}

ROC analysis of UNGAL showed the best discriminative ability at 12 hours: AUC of 0.911 , sensitivity of $88 \%$, specificity of $92 \%$, CI $95 \% 0.852-$ 0.971 and cut-off value of 70, p < 0.001. (Table 2.6, Fig. 2.6) ROC analysis of

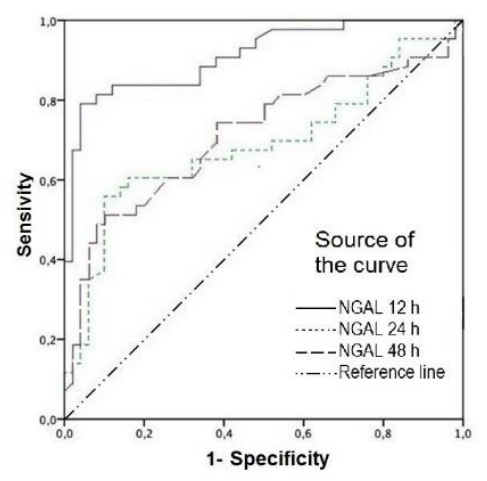

Fig. 2.6 ROC curve of uNGAL at different time points

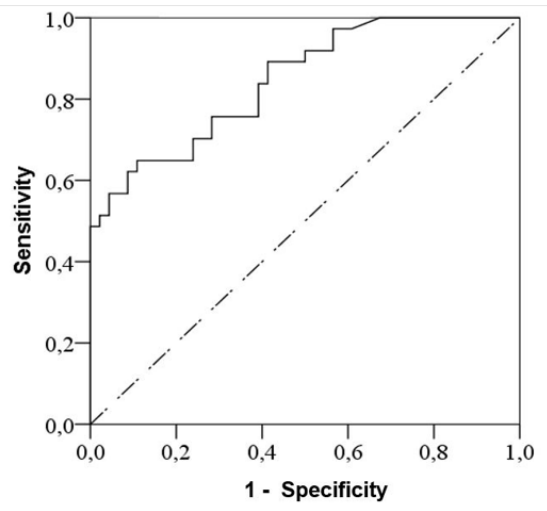

Fig. 2.8 ROC curve of FB POD-1 in AKI and non-AKI patients`1

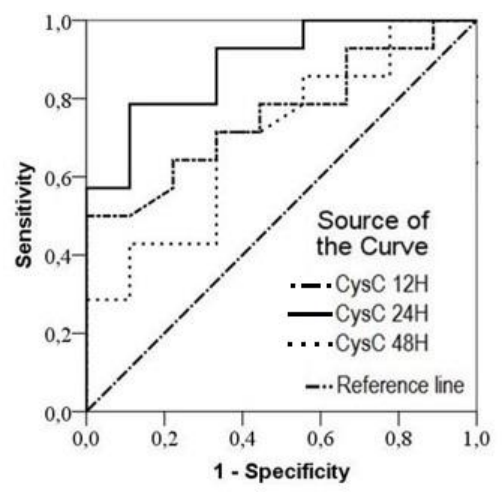

Fig. 2.7 ROC curve of SCys $\mathrm{C}$ at different time points

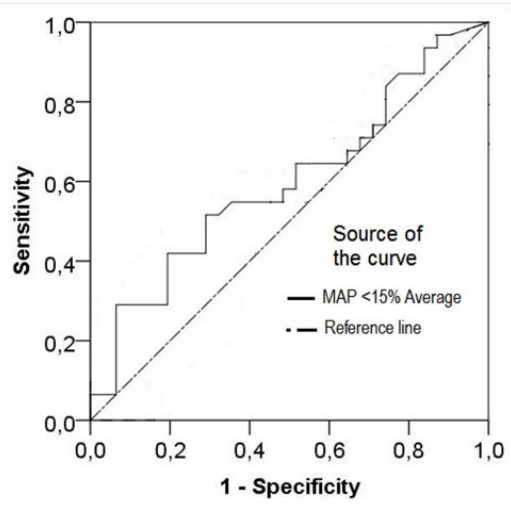

Fig. 2.9 ROC curve of MAP $<15 \%$ from average MAP in AKI and non-AKI patients 
AUC of 0.843 , sensitivity of $81 \%$, specitify of $72 \%$, CI $95 \% 0.843-0.926$, $\mathrm{p}<0.001$ (Table 2.6, Fig. 2.7). ROC analysis of postoperative fluid balance on postoperative day 1 (FB POD-1) showed AUC of 0.842 CI 95\% CI 0.838-0.926, cut-off value of 25, $\mathrm{p}<0.001$ (Table 2.6, Fig. 2.8). ROC analysis of intraoperative hypotension (MAP $<15 \%$ average MAP) showed low sensitivity and specificity: AUC of 0.591 , sensitivity $53 \%$, specificity $65 \%$, CI $95 \% 0.452-$ 0.741, $\mathrm{p}=0.12$ (Table 2.6, Fig. 2.9).

Table 2.6

\section{Sensivity and specificity of various biomarkers at different time points}

\begin{tabular}{|c|c|c|c|c|c|c|c|c|}
\hline $\begin{array}{c}\text { Bio- } \\
\text { marker }\end{array}$ & $\begin{array}{c}\text { Area } \\
\text { under } \\
\text { the } \\
\text { curve } \\
\text { AUC) }\end{array}$ & $\begin{array}{c}\text { Sensi- } \\
\text { vity } \\
(\%)\end{array}$ & $\begin{array}{c}\text { Specifi- } \\
\text { city } \\
(\%)\end{array}$ & $\begin{array}{c}\text { Cut-of } \\
\text { value }\end{array}$ & $95 \%$ CI & $\begin{array}{c}\text { Positive } \\
\text { predic- } \\
\text { tive } \\
\text { value } \\
\text { (PPV) }\end{array}$ & $\begin{array}{c}\text { Negative } \\
\text { predic- } \\
\text { tive } \\
\text { value } \\
\text { (NPV) }\end{array}$ & p value \\
\hline $\begin{array}{c}\text { SCys C } \\
12 \text { H }\end{array}$ & 0.703 & 62 & 70 & 0.96 & $\begin{array}{c}0.589- \\
0.817\end{array}$ & 0.830 & 0.437 & 0.004 \\
\hline $\begin{array}{c}\text { SCys C } \\
24 \text { H }\end{array}$ & 0.843 & 81 & 72 & 0.99 & $\begin{array}{c}0.843- \\
0.926\end{array}$ & 0.939 & 0.413 & $<0.001$ \\
\hline $\begin{array}{c}\text { SCys C } \\
48 \text { H }\end{array}$ & 0.741 & 67 & 75 & 0.79 & $\begin{array}{c}0.627- \\
0.854\end{array}$ & 0.884 & 0.443 & 0.04 \\
\hline $\begin{array}{c}\text { uNGAL } \\
12 \text { H }\end{array}$ & 0.911 & 88 & 92 & 70 & $\begin{array}{c}0.852- \\
0.971\end{array}$ & 0.991 & 0.431 & $<0.001$ \\
\hline $\begin{array}{c}\text { uNGAL } \\
24 \mathrm{H}\end{array}$ & 0.715 & 66 & 74 & 64 & $\begin{array}{c}0.606- \\
0.824\end{array}$ & 0.864 & 0.464 & 0.002 \\
\hline $\begin{array}{c}\text { uNGAL } \\
48 \mathrm{H}\end{array}$ & 0.688 & 59 & 70 & 62 & $\begin{array}{c}0.574- \\
0.802\end{array}$ & 0.812 & 0.436 & 0.011 \\
\hline $\begin{array}{c}\text { FB } \\
\text { POD-1 }\end{array}$ & 0.842 & 80 & 71 & 25 & $\begin{array}{c}0.838- \\
0.926\end{array}$ & 0.936 & 0.399 & $<0.001$ \\
\hline $\begin{array}{c}\text { MAP }< \\
15 \%\end{array}$ & 0.591 & 53 & 65 & 56 & $\begin{array}{c}0.452- \\
0.741\end{array}$ & 0.686 & 0.489 & 0.12 \\
\hline
\end{tabular}

Postoperative fluid balance (FB POD-1) was $13.58 \mathrm{~mL} / \mathrm{kg}$ (Median) in non-AKI group versus $27.20 \mathrm{~mL} / \mathrm{kg}$ in AKI group, $\mathrm{p}=0.025$ (Fig. 2.10) In addition, FB was calculated separately according the severity stage of AKI. Fluid balance in patients reaching $1^{\text {st }}$ stage of AKI severity increased from $13.58 \mathrm{~mL} / \mathrm{kg}$ (Median) to $26.27 \mathrm{~mL} / \mathrm{kg}, 2^{\text {nd }}$ stage to $36.29 \mathrm{~mL} / \mathrm{kg}$ and $3^{\text {rd }}$ stage to 
$90.09 \mathrm{~mL} / \mathrm{kg}$, ANOVA test $\mathrm{p}=0.002$ (Table 2.7, Fig. 2.11). To evaluate postoperative fluid balance as a marker for AKI, ROC analysis was performed (Fig. 2.8, Table 2.6). AUC was 0.842 (CI 95\% 0.838-0.926), sensitivity of $80 \%$, specificity of $71 \%$ and cut-off value of $25 \mathrm{~mL} / \mathrm{kg}$.

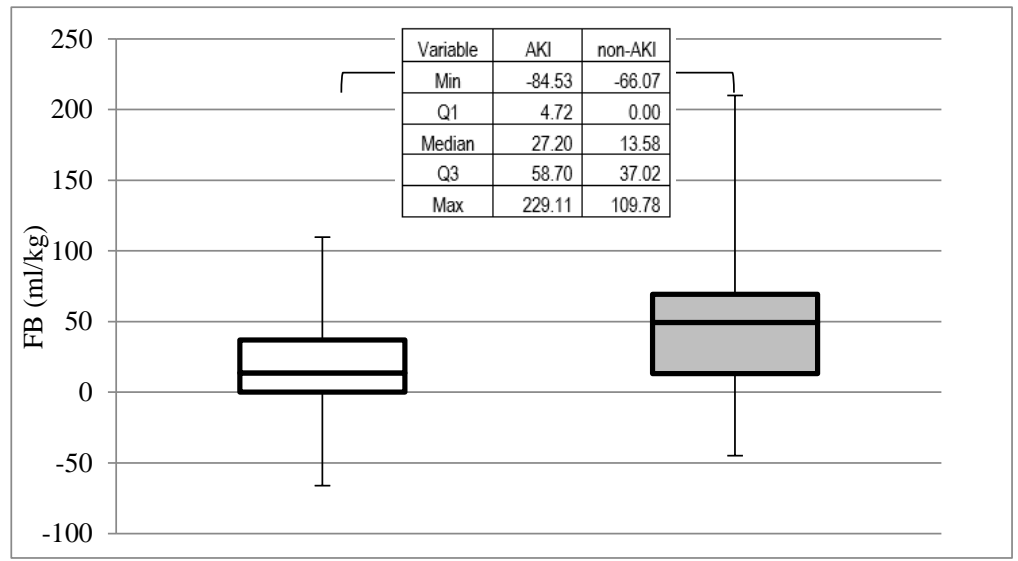

Fig. 2.11 FB at POD-1 in AKI and non-AKI patients

Box and whisker plot showing $\mathrm{FB}(\mathrm{ml} / \mathrm{kg})$ in AKI (filled box) and non-AKI (emtv box) patients

Table 2.7

Postoperative fluid balance $(\mathrm{mL} / \mathrm{kg})$ at POD-1 and severity of AKI

\begin{tabular}{|l|c|c|c|c|}
\hline Variable/Severity & Non-AKI & $\begin{array}{c}\text { AKI I }^{\text {st }} \\
\text { stage }\end{array}$ & $\begin{array}{c}\text { AKI II }^{\text {nd }} \\
\text { stage }\end{array}$ & $\begin{array}{c}\text { AKI III } \\
\text { stage }\end{array}$ \\
\hline Median & 13.58 & 26.27 & 36.29 & 90.19 \\
\hline $\begin{array}{l}\text { Interquartile range } \\
\text { (Q1-Q3) }\end{array}$ & $0-37.02$ & $0-39.63$ & $5.60-58.56$ & $\begin{array}{c}70.97- \\
130.61\end{array}$ \\
\hline Range (Min.-Max.) & $\begin{array}{c}-66.07- \\
109.78\end{array}$ & $\begin{array}{c}-63.10- \\
210.00\end{array}$ & $\begin{array}{c}-44.85- \\
171.01\end{array}$ & $\begin{array}{c}55.25- \\
229.11\end{array}$ \\
\hline
\end{tabular}




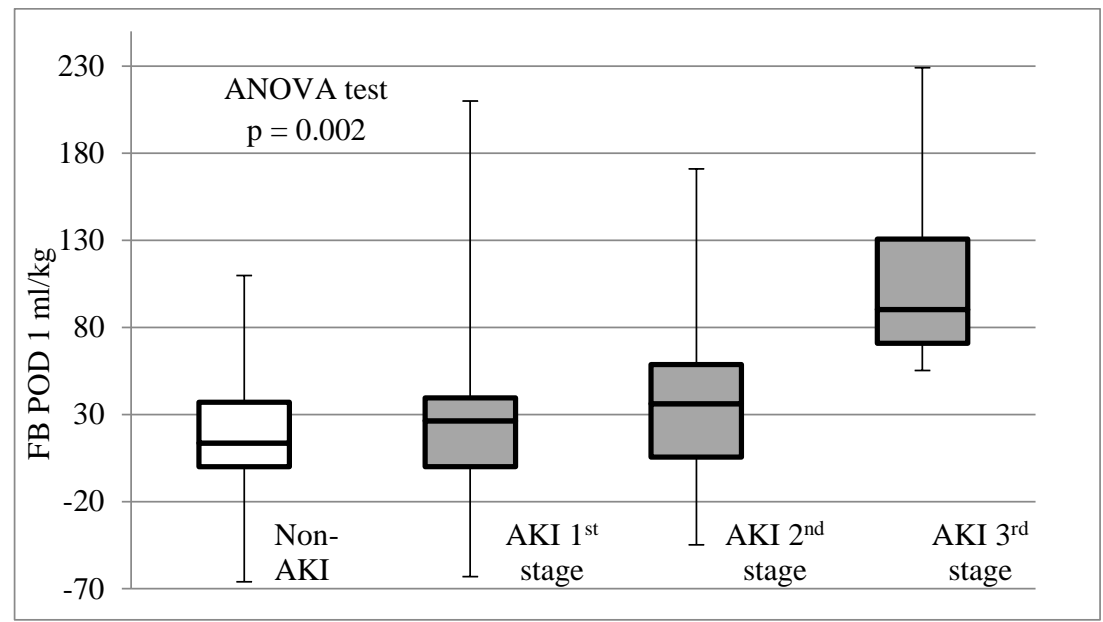

Fig. 2.11 Postoperative FB and severity of AKI

Box and whisker plot showing FB POD-1 in non-AKI patients (emty box) and patients having $\mathrm{I}^{\text {st }}, 2^{\text {nd }}$ and $3^{\text {rd }}$ stage of AKI (filled boxes)

Table 2.8

Intraoperative hypotension in AKI and non-AKI patients

\begin{tabular}{|c|c|c|c|c|}
\hline Variable/Category & All & AKI & Non-AKI & p value* \\
\hline $\begin{array}{c}\text { No of MAP } \\
\text { measurements } \\
\text { (per patient) }\end{array}$ & $\begin{array}{c}42.41 \\
(33.00-50.00)\end{array}$ & $\begin{array}{c}45.32 \\
(35.00-56.00)\end{array}$ & $\begin{array}{c}39.59 \\
(32.25-43.75)\end{array}$ & 0.080 \\
$\begin{array}{c}\text { Median (IQR), } \\
\text { [Range] }\end{array}$ & {$[22.00-80.00]$} & {$[24.00-80.00]$} & {$[22.00-74.00]$} & \\
\hline $\begin{array}{c}\text { Hypotensive } \\
\text { episodes (\% from } \\
\text { all MAP) Median } \\
\text { (IQR) }\end{array}$ & $\begin{array}{c}(9.11-19.92) \\
{[0-33.33]}\end{array}$ & $\begin{array}{c}(12.91-25.80) \\
{[5.56-33.33]}\end{array}$ & $\begin{array}{c}(8.28-14.05) \\
{[0-26.98]}\end{array}$ & 0.075 \\
\hline
\end{tabular}

* Mann-Whitney test

To determine the role of hypotension in the development of postoperative AKI, blood pressure measurements were collected from the Anesthesia Clinical Information system (Intelly View, Philips) and analyzed after transition to MS Excell workbook. In total there were about 4.000 validated MAP reacordings processed. There was no statistically signicicant difference in the number of 
MAP measurements between two groups, 45.32 in AKI group, 35.59 in non-AKI group, $\mathrm{p}=0.08$. There was no difference in the proportion of hypotensive episodes in both groups: 11.03 versus 19.66 in AKI group, $\mathrm{p}=0.075$. Ratio of hypotensive episodes with MAP less than 15\% from average MAP was 19.66 in AKI group versus 11.03 in non-AKI group, $\mathrm{p}=0.075$ (Table 2.8, Fig. 2.12).

ROC analysis of MAP $<15 \%$ shoved low sensitivity and specificity of intraoperative hypotension. AUC was 0.591 with sensitivity of $53 \%$ and specificity of $65 \%$, CI 95\% 0.452-0.741 (Fig. 2.12, Table 2.6).

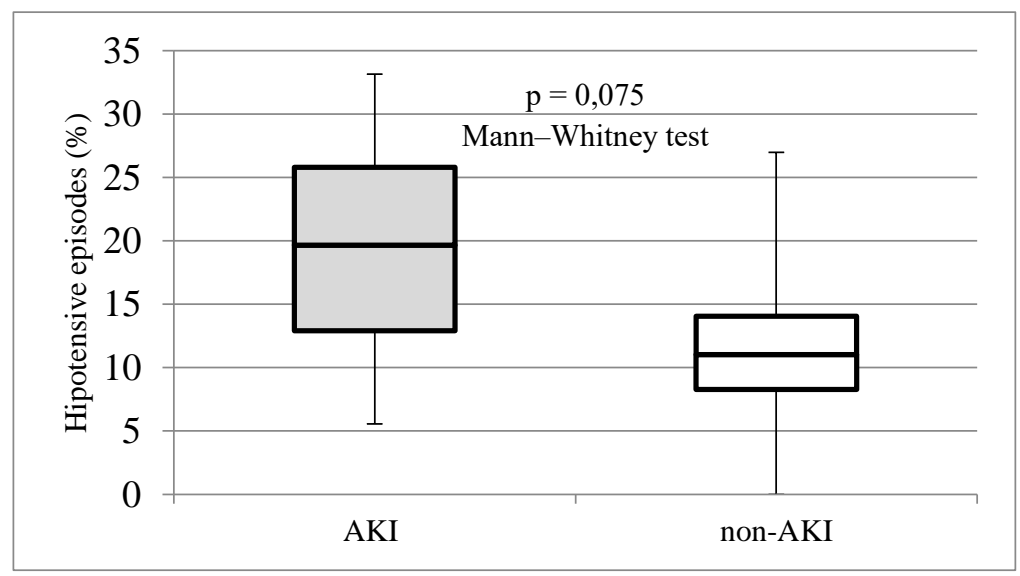

Fig. 2.12 Intraoperative hypotension in AKI and non-AKI patients

Box and whisker plot showing ratio of hypotensive (MAP $<15 \%$ less than averagee MAP value) MAP recordings to all MAP recordings (in \%) in AKI (filled box) and non-AKI patients (emty box).

\subsection{Outcome of AKI}

Duration of mechanical ventilation (MV) was 22 hours in non-AKI group versus 92 hours in AKI group, $\mathrm{p}=0.0001$. Proportion of patients ventilated $\geq 48$ hours in AKI group was $65.10 \%$ versus $26.50 \%$ in non-AKI group, $\mathrm{p}=0.0001$. 
Length of treatment in the hospital, longer than 21 days had $38.09 \%$ of patients in AKI group versus $17.64 \%$ in non-AKI group, $\mathrm{p}=0.035$. Length of treatment in ICU $\geq 5$ days had $21.56 \%$ patients in non-AKI group versus $54.76 \%$ in AKI group, $\mathrm{p}=0.012$. Fluid balance exceeding $50 \mathrm{ml} / \mathrm{kg}$ was observed in $59.52 \%$ patients of AKI group versus $35.29 \%$ of patients from non-AKI group, $\mathrm{p}=$ 0.046. Three patients in AKI group undergo RRT, none in non-AKI group. There was no death in non-AKI group versus two in AKI group, $\mathrm{p}=0.21$ (Table 2.9).

Table 2.9

\section{Clinical outcome characteristics by AKI status}

\begin{tabular}{|l|c|c|c|}
\hline \multicolumn{1}{|c|}{ Variable/category } & Non-AKI & AKI & p value \\
\hline $\begin{array}{l}\text { Mechanical ventilation (hours), } \\
\text { median (IQR) }\end{array}$ & $\begin{array}{c}22.00 \\
(14.00-61.00)\end{array}$ & $\begin{array}{c}92.00 \\
(36.00-216.00)\end{array}$ & $0.0001^{*}$ \\
\hline $\begin{array}{l}\text { Mechanical ventilation } \geq 48 \mathrm{hrs}, \\
\mathrm{n}(\%)\end{array}$ & $13.00(26.50 \%)$ & $28.00(65.10 \%)$ & $0.0001^{\#}$ \\
\hline $\begin{array}{l}\text { FB POD-1 > 50ml/kg, median } \\
(\mathrm{IQR})\end{array}$ & $\begin{array}{c}13.58 \\
(0.00-37.02)\end{array}$ & $\begin{array}{c}27.20 \\
(4.72-58.70)\end{array}$ & $0.025^{*}$ \\
\hline FB POD-1 $\geq 50 \mathrm{ml} / \mathrm{kg}, \mathrm{n}(\%)$ & $18 / 51(35.29 \%)$ & $25 / 42(59.52 \%)$ & $0.046^{\#}$ \\
\hline ICU LOS, days, median (IQR) & $4(4.0-5.5)$ & $7(4.0-12.0)$ & $0.0027^{*}$ \\
\hline ICU LOS, days $\geq 5 \mathrm{n}(\%)$ & $11 / 51(21.56 \%)$ & $23 / 42(54.76 \%)$ & $0.012^{\#}$ \\
\hline $\begin{array}{l}\text { Hospital LOS, days, median } \\
(\text { IQR })\end{array}$ & $13(10.0-21.5)$ & $19(13.0-38.0)$ & $0.0003^{*}$ \\
\hline LOS $\geq 21$ day, n $(\%)$ & $9 / 51(17.64 \%)$ & $16 / 42(38.09 \%)$ & $0.035^{\#}$ \\
\hline RRT & $0 / 51(0.00 \%)$ & $3 / 42(7.14 \%)$ & $0.088^{\#}$ \\
\hline Case fatality rate & $0 / 51$ & $2 / 42$ & $0.21^{\#}$ \\
\hline
\end{tabular}

"Fisher's exact test, "Mann-Whitney U test

Table 2.10

Duration of mechanical ventilation, lenghts of stay in the ICU, lenghts of stay in the hospital in AKI and non-AKI patients

\begin{tabular}{|c|c|c|c|}
\hline Variable, category & AKI & Non-AKI & $\mathrm{p}$ value \\
\hline $\begin{array}{l}\text { Mechanical ventilation hours, } \\
\text { Median (IQR) [Range] }\end{array}$ & $\begin{array}{c}92.00 \\
(36.00-216.00) \\
{[4.00-408.00]}\end{array}$ & $\begin{array}{c}22.00(14.00- \\
61.00)[6.00- \\
179.00]\end{array}$ & $0.0001 *$ \\
\hline $\begin{array}{l}\text { Lenghts of stay in the ICU days, } \\
\text { Median (IQR) [Range] }\end{array}$ & $\begin{array}{c}7.0(4.0-12.0) \\
{[3.00-20.00]}\end{array}$ & $\begin{array}{l}4.0(4.0-5.5) \\
{[3.00-18.00]}\end{array}$ & $0.0001 *$ \\
\hline $\begin{array}{l}\text { Lenghts of stay in the hospital } \\
\text { days, Median (IQR) [Range] }\end{array}$ & $\begin{array}{l}19(13.0-38.0) \\
{[7.00-116.00]}\end{array}$ & $\begin{array}{c}13(10.0-21.5) \\
{[3.00-43.00]}\end{array}$ & $0.0027 *$ \\
\hline
\end{tabular}

* Mann-Whitney U test 


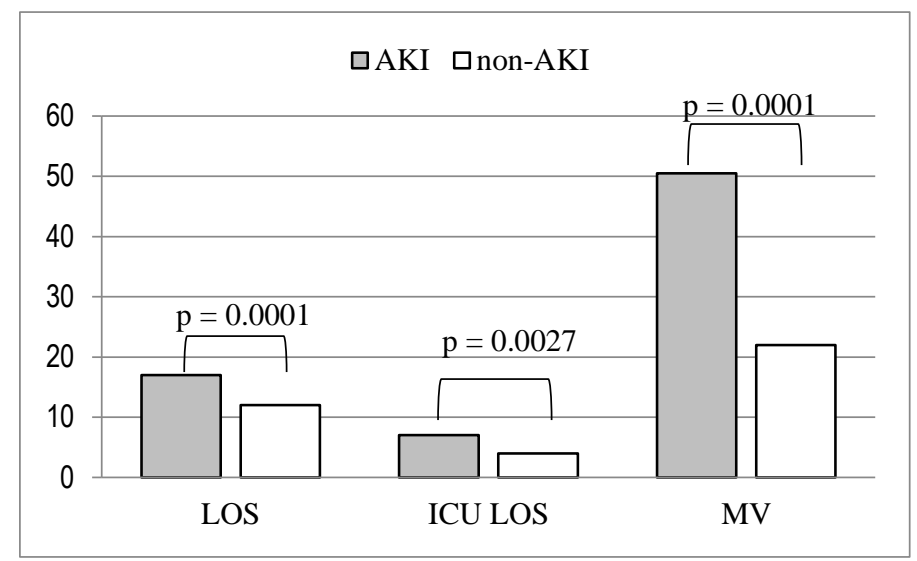

Fig. 2.13 Median values of LOS, ICU LOS (days) and duration of MV (hours) in AKI and non-AKI patients Abbreviations: LOS - Lengths of stay in the hospital, ICU LOS Lengths of stay in the ICU, MV - Mechanical ventilation

OR were calculated to assess factors, associated with postoperative renal dysfunction. One of the variables was CPB time. Unajusted OR for CPB time $\geq 180$ min. was 2.47 (CI 95\% 0.99-6.13, $\mathrm{p}=0.048$, Table 2.9). OR for mechanical ventilation $>2$ days was $5.17(\mathrm{CI} 95 \%$ 2.12-12.61, $\mathrm{p}=0.027$ ). OR for ICU LOS $\geq 5$ days was 4.4 (CI 95\% 1.78-10.85, $\mathrm{p}=0.0012$, Table 2.9).

After performing multivariate logistic regression analysis OR were adjusted to age and summarized in Table 2.11.

After the adjustment for age, OR for ICU LOS > 5 days decreased from 4.40 (CI 95\% 1.78-10.85) to 1.21 (CI 95\% 1.07-1.40), $\mathrm{p}=0.003$. OR for LOS $\geq 21$ day decreased from 2.87 (CI 95\% 1.11-7.44) to 1.046, (CI 95\% 1.009 1.085 ), $\mathrm{p}=0.035$. OR for CPB time $\geq 180 \mathrm{~min}$. from 2.47 (CI 95\% 0.99-6.13), decreased to 2.32 (CI 95\% 1.07-1.40), $\mathrm{p}=0.003$. OR for $\mathrm{MV} \geq 48$ hours after the adjustment for age from 5.17 (CI 95\% 2.12-12.61), decreased to 1.008 (CI 95\% 1.003-1.014), $\mathrm{p}=0.004$. OR for VIS $\geq 7$ from 12.26 (CI 95\% 4.05-37.11), 
decreased to 5.85 (CI 95\% 5.85-56.66), $\mathrm{p}<0.001$. OR for FB POD-1 $\geq 50$ $\mathrm{mL} / \mathrm{kg}$ from 2.69 (CI 95\% 1.16-6.26) dereased to 2.58 (CI 95\% 0.94-7.07), $\mathrm{p}=0.06$. OR for RACHS $-1 \geq 3$ from 2.98 (CI 95\% 1.28-6.95) decreased to 2.86 (CI 95\% 1.15-7.15), $\mathrm{p}=0.02$.

Table 2.11

Odds ratio in $\mathrm{AKI}$ and non-AKI patients

\begin{tabular}{|l|c|c|}
\hline \multicolumn{1}{|c|}{ Variable } & OR (CI 95\%) & p value \\
\hline AKI versus non-AKI, CPB time $\geq 180 \mathrm{~min}$. & $2.47(0.99-6.13)$ & $0.048^{\#}$ \\
\hline AKI versus non-AKI, body weight $<8 \mathrm{~kg}$ & $1.82(0.77-4.31)$ & $0.201^{\#}$ \\
\hline $\begin{array}{l}\text { AKI versus non-AKI, mechanical ventilation } \\
>2 \text { days, OR (CI 95\%) }\end{array}$ & $5.17(2.12-12.61)$ & $0.027^{\#}$ \\
\hline $\begin{array}{l}\text { AKI versus non-AKI, ICU LOS } \geq 5 \text { days OR } \\
(\text { CI 95\%) }\end{array}$ & $4.40(1.78-10.85)$ & $0.0012^{\#}$ \\
\hline $\begin{array}{l}\text { AKI versus non-AKI, LOS } \geq 21 \text { day OR (CI } \\
95 \%)\end{array}$ & $2.87(1.11-7.44)$ & $0.035^{\#}$ \\
\hline AKI versus non-AKI FB POD-1 $\geq 50 \mathrm{~mL} / \mathrm{kg}$ & $2.69(1.16-6.26)$ & $0.026^{\#}$ \\
\hline AKI versus non-AKI VIS $\geq 7$ & $12.26(4.05-37.11)$ & $<0.0001^{\#}$ \\
\hline AKI versus non-AKI RACHS-1 score $\geq 3$ & $2.98(1.28-6.95)$ & $0.01^{\#}$ \\
\hline
\end{tabular}

"Fisher's exact test

Table 2.12

Age adjusted Odds ratio

\begin{tabular}{|l|c|c|c|}
\hline \multicolumn{1}{|c|}{ Variable } & Odds ratio & CI $(95 \%)$ & p value \\
\hline ICU LOS $\geq 5$ days AKI vs. non-AKI & 1.21 & $1.07-1.40$ & 0.003 \\
\hline $\mathrm{CPB} \geq 180$ min. AKI vs. non-AKI & 2.32 & $0.91-5.91$ & 0.07 \\
\hline RACHS-1 $>3$ AKI vs. non-AKI & 2.86 & $1.15-7,15$ & 0.02 \\
\hline VIS $\geq 7$ AKI vs. non-AKI & 5.85 & $5.85-56.66$ & 0.001 \\
\hline MV $\geq 48$ hours AKI vs. non-AKI & 1.008 & $1.003-1.014$ & 0.004 \\
\hline LOS $\geq 21$ days AKI vs. non-AKI & 1.046 & $1.009-1.085$ & 0.01 \\
\hline FB $\geq 50 \mathrm{~mL} / \mathrm{kg}$ AKI vs. non-AKI & 2.58 & $0.94-7.07$ & 0.06 \\
\hline
\end{tabular}

Values are reported as adjusted odds ratios ( $95 \%$ confidence intervals) by multivariate logistic regression analysis. Odds ratio analyses for all patients are per unit increase. 


\section{DISCUSSION}

Despite many years of research, AKI remains an important and lifethreatening complication in patients undergoing cardiac surgery, and with respect to high prevalence of this interference in this specific population has even got a sub-designation: CSA-AKI [14].

Postoperative AKI occurred in 42 (45.16\%) from 93 children. $37(88.02 \%)$ reached severity stage I according the KDIGO classification, $3(7.14 \%)$ reached stage II and two (4.76\%) reached stage III. (Fig. 2.2, 2.3). Prior to 2005 there were no studies of cardiac surgery associated AKI using the currently accepted definition. These studies used definitions ranging from doubling of serum creatinine to requirement of dialysis. Pederson et al. [15] performed one of the larger single center prospective studies enrolling children from 1993 to 2002 and used dialysis as their AKI definition. They found that $11.5 \%$ of their patients developed AKI. However, the use of dialysis as the definition of AKI is concerning since most clinicians agree that AKI develops before the need for dialysis. In a large study of by Zappitelli et al. 35.9\% of all children having cardiac surgery developed AKI [16].

Analysis of preoperative risk factors demonstrated that children who were in the youngest age group were at higher risk for developing AKI compared to the older age groups (Table 2.4) The reason for this is not completely clear. Though full-term infants are usually born with their full complement of nephrons, maximal GFR is not achieved until about 2 years of age [17]. Thus, children less than 2 years old may be more susceptible to the ischemic and inflammatory insults that may be occurring in patients undergoing heart surgery. Examples of these surgeries include simple ASD closures and repair of partially anomalous pulmonary veins. This is not surprising since these surgeries are less complex and relatively rapid with low CPB times [18]. 
The finding that higher RACHS-1 scores were associated with higher prevalence of postoperative AKI. [7, 19]. RACHS-1 score $\geq 3$ had 18/51 patients $(35.29 \%)$ in non-AKI group versus $26 / 42$ patients $(61.90 \%)$ in AKI group, $\mathrm{p}=0.0129$ (Table 2.4). In the multivariate regression analysis OR for RACHS-1 >3 AKI vs. non-AKI was 2.86 CI 95\% 1.15-7.15, $\mathrm{p}=0.02$ (Table 2.12) Garcia et al. evaluated the Vasoactive Inotropic Score (VIS) as a prognostic marker in adolescents following surgery for congenital heart disease. They found that maximal VIS at 24 and $48 \mathrm{~h}$ following surgery was significantly higher in subjects who suffered an adverse outcome [20]. Subjects with adverse outcome had longer bypass and cross-clamp times, durations of stay in the hospital, and a higher rate of acute kidney injury. In current study VIS score in non-AKI group was 5 (IQR 5-6) versus 7 (IQR 6-10) in AKI group, p = 0.0098 (Table 2.4). In multivariate regression analysis OR for VIS $\geq 7$ was 5.85 (CI 95\% 5.85-56.66), $\mathrm{p}<0.001$, Table 2.12.

Not surprisingly, the duration of $\mathrm{CPB}$ has been the single most consistently identified risk factor for pediatric CS-AKI. Age-adjusted OR for CPB time $\geq 180$ min. AKI versus non-AKI patients was 2.32 (CI 95\% $1.07-$ 1.40), $\mathrm{p}=0.003$ (Table 2.12). This finding of increased risk of AKI is consistent with numerous past studies. The mechanism for this is probably due to a combination of ischemia, loss of pulsatile flow and progressive inflammation which adds to kidney injury [21]. Further research into issues such as temperature, pressure and the amount and type of bypass circuit flows will be needed to explore this relationship. Strategies to limit bypass time may help decrease the rate of cardiac surgery-associated AKI. It is possible that in children who have surgery requiring bypass the duration may also be a marker for case complexity and severity of the congenital anomaly. Adults undergoing cardiac surgery typically have several pre-operative cardiovascular risk factors such as diabetes, peripheral vascular disease, and chronic kidney disease. 
These same risk factors often emerge as pre-operative cardiovascular risk factors for developing AKI in adults [22]. In children with congenital heart disease these factors are not usually present. In fact, most children do not have any other comorbidities. Risk factors for AKI in children are usually limited to the age of the child and the severity of insult (e.g. CPB time).

The use of Cystatin $\mathrm{C}$ as a diagnostic tool for AKI has recently been explored. Two meta-analyses have revealed that serum cystatin $\mathrm{C}$ outperforms $\mathrm{SCr}$ as a predictor of AKI and a marker of AKI severity [23, 24]. A multicenter prospective study of children undergoing cardiac surgery showed that early measurements of cystatin $\mathrm{C}$ (within $6 \mathrm{~h}$ of initiating CPB) strongly and independently predicted the development of SCr-based AKI with an adjusted odds ratio of 17.2 and adjusted area under the receiver operating characteristic curve (AUC) of 0.89 [25].

Serum Cystatin C concentrations were similar in the AKI and non-AKI patients before surgery but began to increase in the AKI patients at 12 hours after $\mathrm{CPB}$ and became significantly higher at 24 hours after CPB. (Fig. 2.7, Table 2.5) SCys C levels rise from the baseline to $1.06 \mathrm{mg}$ (IQR 0.83-1.37) after 12 hours and reached their maximum at 24 hours after surgery: $1.31 \mathrm{mg} / \mathrm{L}$ (IQR 1.06-1.48) in AKI group versus $0.77 \mathrm{mg} / \mathrm{L}$ (IQR 0.63-1.06) in non-AKI group, $\mathrm{p}$ $=0.0002$ (Fig. 2.7, Table 2.5). In the ROC analysis, predictor performance for SCys C peaked 24 hours after the first probe was taken and reached AUC of 0.843 , (CI $95 \% 0.843-0.926$ ), with sensitivity of $81 \%$, specificity of $72 \%$ and cut-off of $0.99 \mathrm{mg} / \mathrm{L}, \mathrm{p}<0.001$ (Table 2.7, Fig. 2.7).

The most extensively studied biomarker in pediatric CS-AKI is NGAL. It was measured in more than 7000 patients after cardiac surgery can predict the subsequent development of AKI (AUC 0.82-0.83). Most recently, the multicenter TRIBE (Translational Research Involving Biomarkers and Endpoints) study [26], prospectively assessed the value of NGAL in 1219 adults and 311 children undergoing cardiac surgery. In both populations, NGAL 
concentrations measured in urine or plasma peaked within $6 \mathrm{~h}$ after surgery and significantly improved risk prediction over the clinical models alone [27]. In pediatrics, uNGAL levels demonstrated sharp increases to $>5000 \mathrm{ng} / \mathrm{mg}$ within 2-4 hours in patients who would eventually require RRT [28]. Urinary NGAL (uNGAL) levels of $\geq 50 \mu \mathrm{g} / \mathrm{L}$ were $100 \%$ sensitive and $98 \%$ predictive in the 20 from 71 children post CPB who developed AKI [17]. Serum NGAL levels within 2 hours of CPB of $\geq 150 \mathrm{mg} / \mathrm{L}$ were $84 \%$ sensitive and $94 \%$ predictive in children who developed AKI within 3 days [116]. However, Parikh et al. [27] demonstrated lower values for the prediction of AKI in children, defined as doubling in creatinine or the need for acute RRT (AUC approximately 0.7) and lower cut-off values. The reasons for this discrepancy may include the different patient populations (exclusion of neonatal patients), differences in assay platforms and prolonged sample storage times compared to earlier single-centre studies. Indeed, recent study has shown that the performance of NGAL in older adults is inferior to that in children, likely related to the comorbidities (such as chronic kidney disease, chronic heart failure, atherosclerosis, diabetes, medications) that can hinder NGAL's predictive ability [28-30]. Second, there are no uniformly accepted cut-offs, although the literature would suggest that an NGAL cut-off value of $<100 \mathrm{ng} / \mathrm{ml}$ (measured on a standardized clinical platform) would rule out AKI in those with normal baseline function, and a cut-off $>150 \mathrm{ng} / \mathrm{ml}$ can be diagnostic for AKI, Cut-offs may be dependent on age, gender, underlying clinical setting, and the specific assay employed.

Concentration of uNGAL has the maximum expression at 12 hours after surgery. It rises from $7.05 \mathrm{ng} / \mathrm{mL}(2.7-12.13)$ to $132.85 \mathrm{ng} / \mathrm{mL}(60.78-257.23)$, reaching a peak level of $1680 \mathrm{ng} / \mathrm{mL}$ in AKI group. In the probe taken at 24 hours expression of uNGAL gradually decreases to $36.60 \mathrm{ng} / \mathrm{mL}$ in AKI group and $13.40 \mathrm{ng} / \mathrm{mL}$ in non-AKI group. At 48 hours uNGAL level returns to baseline: $7.40 \mathrm{ng} / \mathrm{mL}$ (4.00-23.20) in AKI group and $4.80 \mathrm{ng} / \mathrm{mL}(2.20-15.00)$ in non-AKI group (Fig. 2.5, Table 2.5). In the ROC analysis, predictor performance 
for uNGAL at 12 hours was AUC 0.911, CI 95\% 0.852-0.971, cut-off value $70 \mathrm{ng} / \mathrm{mL}$ (Table 2.6, Fig. 2.5).

Studies of adult critically ill patients have shown that positive FB above $10 \%$ is associated with a higher long-term mortality and a higher occurrence of AKI, thus indicating this threshold as a potential indicator of adverse outcomes $[31,32]$. Studies of pediatric patients requiring RRT showed a correlation of the degree of positive FB with poor outcomes and mortality, hinting at a dynamic positive FB value for predicting adverse outcomes, with the $10 \%$ cut-off value proving to be clinically significant [33]. Recent study by Hazle et al. [34] demonstrates that increasing positive FB, as measured by daily fluid balance, is associated with worse outcomes following congenital heart surgery in infants. In the recent study of Lex et al. authors analyze postoperative FB in 1520 pediatric patients after open heart surgery [208]. They find positive FB between 5\% and $10 \%$ in 120 patients $(7.8 \%)$, in 33 patients $(2.1 \%)$ FB was above $10 \%$. After multivariable analysis, higher fluid overload on the day of the surgery was independently associated with mortality (adjusted odds ratio, 1.14; 95\% CI, $1.008-1.303 ; \mathrm{p}=0.041$ ) and low cardiac output syndrome (adjusted odds ratio, $1.21 ; 95 \% \mathrm{CI}, 1.12-1.30 ; \mathrm{p}=0.001$ ). Higher maximum SCys $\mathrm{C}$ levels (adjusted odds ratio, 1.01; 95\% CI, 1.003-1.021; $\mathrm{p}=.009)$, maximum vasoactive-inotropic scores (adjusted odds ratio, 1.01; 95\% CI, 1.005-1.029; $\mathrm{p}=0.042$ ), and higher blood loss on the day of the surgery (adjusted odds ratio, 1.01; 95\% CI, 1.004$1.025 ; \mathrm{p}=0.015$ ) were associated with a higher risk of fluid overload that was greater than $5 \%$.

The etiology of positive FB in this patient population is multifactorial. Cardiopulmonary bypass results in both hemodilution and increased capillary permeability, both of which promote extravasation of fluid into the extracellular fluid compartment [35]. Fluid resuscitation and blood product administration in the immediate postoperative period further contributes to third spacing. As body wall edema increases, intra-abdominal pressure rise and renal perfusion pressure 
is decreased [36]. When combined with postoperative myocardial dysfunction, there is also a stimulus to retain fluid via the renin-angiotensin-aldosterone system [37]. Given the acute nature of CPB mediated kidney injury and the observation that most infants have normal renal function prior to surgery, these patients may be ideal candidates for aggressive postoperative goal-directed protocols aimed at minimization of positive FB. Peritoneal dialysis has been shown to be a safe and effective method of fluid removal in postcardiotomy infants [38], and early initiation of this therapy can improve hemodynamics and ICU outcomes [39].

By examining fluid balance early after cardiac surgery, current study adds to the growing body of evidence that positive fluid balance is independently associated with kidney dysfunction. FB POD-1 $\geq 50 \mathrm{~mL} / \mathrm{kg}$, in AKI group was $35.29 \%$ versus $59.52 \%$ in AKI group, $\mathrm{p}=0.046$ (Table 2.9). Median postoperative fluid balance in non-AKI group was $13.58 \mathrm{~mL} / \mathrm{kg}$ versus 27.20 $\mathrm{mL} / \mathrm{kg}$ in AKI group, $\mathrm{p}=0.025$ (Fig. 2.10), OR of $\mathrm{FB} \geq 50 \mathrm{~mL} / \mathrm{kg}$ in AKI vs. non-AKI was 2.58 (CI 95\% 0.94-7.07), $\mathrm{p}=0.06$. After performing ROC analysis, AUC of FB POD-1 was 0.842 with sensitivity of $80 \%$, specificity of $71 \%$ (CI 95\% 0.838-0.926) and cut-off value of $25 \mathrm{ml} / \mathrm{kg}, \mathrm{p}=0.001$. Similar results are published in the study of Hassinger et al. [40]. They found postoperative positive fluid balance $>50 \mathrm{ml} / \mathrm{kg}$ in $31 \%$ of patients which is less than in this study (59.52\%). Reported AUC was 0.963; 95\% CI, 0.916-1.000; $\mathrm{p}=0.002$.

The kidneys account for less than $5 \%$ of total body weight and yet receive about $25 \%$ of our cardiac output, to maintain glomerular filtration and waste excretion, they only consume $5 \%$ of the body's oxygen. It is of no surprise, therefore, that targeting adequate renal perfusion is considered as a potential factor for modifying the risk of AKI. It is commonly purported that poor perioperative hemodynamic control during cardiac surgery leads to postoperative CS-AKI. 
Study of Lehman et al. [41] evaluated hypotension severity and duration as risk factors for AKI development using a large ICU database. Results from multivariate logistic regression indicate that the severity and duration of hypotension are both significant risk factors in AKI development in ICU patients. Odds of AKI increased by $3 \%$ per $1 \mathrm{mmHg}$ decrease in MAP below $80 \mathrm{mmHg}$. Further, as the degree of hypotension worsened, the increased risk for AKI from each additional hour of continuous hypotension more than doubled for each $10 \mathrm{~mm} \mathrm{Hg}$ drop in MAP below $80 \mathrm{mmHg}$. These results indicate that raising MAP targets during CPB might reduce the frequency of postoperative AKI. Kanji et al. [42] in their study on 157 high-risk cardiac patients establish a relationship between intraoperative hypotension and postoperative CS-AKI.

Delta MAP was defined as baseline MAP (acquired from three independent pre-operative blood pressure readings) minus the average MAP on $\mathrm{CPB}$ (calculated as the average of MAP readings at 15 minutes intervals during CPB). They found that a large delta MAP and lower CPB flow during cardiac surgery are independently associated with early post-operative CSA-AKI in high-risk patients. In children, however, it is difficult to obtain correct baseline MAP measurements before tracheal intubation and surgical intervention. In pediatric anesthesia induction and tracheal intubation usually precedes vascular cannulation and invasive pressure monitoring, therefore average MAP during anesthesia was used as a reference and hypotension was defined as a MAP $<15 \%$ less than average MAP value. Blood pressure measurements during CPB were also excluded since nonpulsatile CPB perfusion pressure variation is dissimilar to blood pressure variation unrelated to $\mathrm{CPB}$. In total, more than 4.000 validated MAP recordings collected in 5-minute intervals were transferred from the Intelly View Clinical Information Portfolio (Philips) anesthesia flowsheets to MS Excell workbook for analysis. Then all MAP recordings were compared to average (except MAP recordings during $\mathrm{CPB}$, when pulsatile blood flow was absent). Ratio of hypotensive MAP recordings (MAP $<15 \%$ less than average 
MAP value) to total MAP recordings was calculated and expressed as $\%$. There were $12.29 \%$ (IQR 9.11-19.92) hypotensive MAP recordings in all patients, $19.66 \%$ (IQR 12.91-25.80) in AKI group versus $11.03 \%$ (8.28-14.05) in non-AKI group, (Table 2.8, Fig. 2.12). ROC analysis showed an AUC of 0.591 with sensitivity of $53 \%$ and specificity of $65 \%$, CI $95 \% 0.452-0.741(\mathrm{p}=0.12)$, Table 2.6, Fig. 2.9.

Duration of mechanical ventilation in patients with or without AKI is displayed in Table 2.9. Twenty-eight patients $(65.10 \%)$ of those with some degree of AKI were mechanically ventilated $\geq 48$ hours compared with 13 patients $(26.50 \%)$ of those with no evidence of AKI $(\mathrm{p}=0.0001)$.

Median duration of mechanical ventilation (MV) was 22 hours in nonAKI group versus 50.50 hours in AKI group, $\mathrm{p}=0.0001$ (Table 2.9). Multivariate logistic regression analysis demonstrated that patients with AKI were more likely to have longer ICU and hospital lengths of stay: OR for ICU LOS $\geq 5$ days was 1.21 (CI 95\% 1.07-1.40), $\mathrm{p}=0.003$. OR for LOS $\geq 21$ was 1.046, (CI 95\% 1.009-1.085), $\mathrm{p}=0.035$ (Table 2.12). Previous studies [9, 15, 43] have showed younger age to be associated with longer ICU and hospital lengths of stay but have not explored the impact of AKI specifically or defined AKI simply as the need for renal replacement therapy [43]. The longer lengths of stay may be related to fluid retention and concomitant effects on respiratory mechanics causing longer durations of mechanical ventilation, the heterogeneous nature of $\mathrm{CHD}$, institutional and practice guidelines (e.g., no protocol for early extubations), use of diuretics, and limited practice variation. The impact of longer lengths of stay, including increased risks of nosocomial infections medical errors, and greater utilization of resources, with associated escalation of health care costs, are well known [44].

No degree of AKI was associated with in-hospital mortality, irrespective of the age group examined. This is likely related to the relatively low rate of occurrence of in-hospital mortality. 


\section{CONCLUSIONS}

1. The rate of AKI in the current approach of pediatric cardiac surgery in Latvia is high and is associated with important patient outcomes. From 93 patients included in the study, $42(45.2 \%)$ met at least KDIGO Stage I (UO or SCr) criteria for AKI.

2. This study shows that both uNGAL and Cys $\mathrm{C}$ levels after pediatric openheart surgery increase following ICU admission and peak, respectively, 12 to 24 thereafter: uNGAL reliably discriminated between infants who met AKI criteria within 48 hours following admission and those who did not. uNGAL was able to predict AKI development correctly in $91 \%$ children, before any rise in $\mathrm{SCr}$ became apparent. These findings support the emerging role of UNGAL in identifying AKI at an early stage, which, in the future, may help us to establish timely renoprotective interventions to reduce AKI in those most vulnerable patients in hospital.

SCys C, a GFR marker of renal dysfunction predicted AKI in $84 \%$ of children undergoing open heart surgery in 24 hours after the event preceding concomitant changes in SCr.

3. Fluid balance too, is a suitable marker for the prediction of postoperative AKI. FB POD-1 $\geq 50 \mathrm{~mL} / \mathrm{kg}$, in non-AKI group had $35.29 \%$ patients versus $59.52 \%$ in AKI group, $\mathrm{p}=0.046$. Median postoperative fluid balance in nonAKI group was $13.58 \mathrm{~mL} / \mathrm{kg}$ versus $27.20 \mathrm{~mL} / \mathrm{kg}$ in AKI group, $\mathrm{p}=0.025$, $\mathrm{OR}$ of $\mathrm{FB} \geq 50 \mathrm{~mL} / \mathrm{kg}$ in AKI versus non-AKI was 2.58 (CI 95\% 0.94-7.07), $\mathrm{p}=0.06$. After performing ROC analysis, AUC of FB POD-1 was 0.842 with sensitivity of $80 \%$, specificity of $71 \%$ (CI 95\% $0.838-0.926$ ) and cut-off value of $25 \mathrm{ml} / \mathrm{kg}, \mathrm{p}=0.001$. Role of fluid balance in the postoperative management is underestimated and daily FB monitoring now becomes essential. 
4. The hypothesis of the association of intraoperative hypotension and postoperative AKI was not confirmed using methodology, applied in this study.

5. CS-AKI had severe clinical outcomes: MV in AKI group was 50.50 hours (IQR 36.50-201.00) versus 22.00 hours (IQR 14.50-50.00) in non-AKI group, $\mathrm{p}=0.0001$. Lengths of ICU stay increased from 4.00 days (IQR 4.00-5.00) in non-AKI group to 7.00 days (IQR 4.50-11.50) in AKI group, $\mathrm{p}=0.0001$. LOS increased from 12.00 days (IQR 10.00-20.00) in non-AKI group to 17.00 days (IQR 10.00-20.00), $\mathrm{p}=0.023$. In multivariate regression analysis OR for ICU LOS $>5$ days was 1.21 (CI 95\% 1.07-1.40), $\mathrm{p}=0.003$. OR for $\operatorname{LOS} \geq 21$ was 1.046 , (CI 95\% 1.009-1.085), $\mathrm{p}=0.035$. OR for $\mathrm{MV} \geq 48$ hours after the adjustment for age was 1.008 (CI 95\% $1.003-1.014), \mathrm{p}=0.004$. 


\section{REFERENCES}

1. Yap SC, Lee TH. 2012. Acute Kidney Injury and Extrarenal Organ Dysfunction New Concepts and Experimental Evidence. Anesthesiology. 116, 1139-1148.

DOI; 10.1097/ALN.0b013e31824f951b.

2. Chertow GM, Levy EM, Hammermeister KE, et al. 1998. Independent Association Between Acute Renal Failure and Mortality Following Cardiac Surgery. Am J Med. 104, 343-348.

3. Beger RD, Holland RD, Sun J, et al. 2008. Metabonomics of Acute Kidney Injury After Cardiac Surgery. Pediatr Nephrol. 23, 977-984.

4. Xue JL, Daniels F, Star RA, et al. 2006. Incidence and Mortality of Acute Renal Failure in Medicare Beneficiaries, 1992 to 2001. J Am Soc Nephrol. 17, 1135-1142.

5. Sanchez-Pinto LN, Goldstein SL, Schneider JB, et al. 2015. Association Between Progression and Improvement of Acute Kidney Injury and Mortality in Critically Ill Children. Pediatr Crit Care Med. 16, 703-710.

DOI:10.1097/PCC.0000000000000461

6. Schneider J, Khemani R, Grushkin C, et al. 2010. Serum Creatinine as Stratified in the RIFLE Score for Acute Kidney Injury is Associated with Mortality and Length of Stay for Children in the Pediatric Intensive Care Unit. Crit Care Med. 38, 933-939. DOI: 10.1097/CCM.0b013e3181cd12e1.

7. Aydin SI, Seiden S, Blaufox AD, et al. 2012. Acute Kidney Injury After Surgery for Congenital Heart Disease. Ann Thorac Surg. 94, 1589-1595.

DOI: $10.1016 /$ j.athoracsur.2012.06.050.

8. Li S, Krawczeski CD, Zappitelli M. et al. 2011. Incidence, Risk Factors, and Outcomes of Acute Kidney Injury After Pediatric Cardiac Surgery: A Prospective Multicenter Study. Crit Care Med. 39, 1493-1499.

DOI: 10.1097/CCM.0b013e31821201d3.

9. Uchino S, Kellum JA, Bellomo R. et al. 2005. Acute Renal Failure in Critically Ill Patients: A Multinational, Multicenter Study. JAMA. 294, 813-818.

DOI:10.1001/jama.294.7.813

10. Bellomo R, Ronco C, Kellum JA, et al. 2004. Acute Renal Failure-Definition, Outcome Measures, Animal Models, Fluid Therapy and Information Technology Needs: The Second International Consensus Conference of the Acute Dialysis Quality Initiative (ADQI) Group. Crit Care. 8; R204-R212. DOI: 10.1186/cc2872

11. Jenkins KJ. 2004. Risk Adjustment for Congenital Heart Surgery: The RACHS-1 Method. Semin Thorac Cardiovasc Surg Pediatr Card Surg Annu. 7, 180-184.

12. KDIGO: Clinical Practice Guideline for Acute Kidney Injury. 2012. Section 2: AKI Definition. Kidney Int Suppl. 2, 19-36. 
13. Gaies MG, Gurney JG, Yen AH, et al. 2010. Vasoactive-Inotropic Score as a Predictor of Morbidity and Mortality in Infants after Cardiopulmonary Bypass. Pediatr Crit Care Med. 234-238. DOI: 10.1097/PCC.0b013e3181b806fc.

14. Sorof JM, Stromberg D, Brewer ED, et al. 1999. Early Initiation of Peritoneal Dialysis after Surgical Repair of Congenital Heart Disease. Pediatr Nephrol. 13, 641-645.

15. Pedersen KR, Povlsen JV, Christensen S, et al. 2007. Risk Factors for Acute Renal Failure Requiring Dialysis after Surgery for Congenital Heart Disease in Children. Acta Anaesthesiol Scand. 51, 1344- 1349.

16. Zappitelli M, Bernier PL, Saczkowski RS, et al. 2009. A Small Post-Operative Rise in Serum Creatinine Predicts Acute Kidney Injury in Children Undergoing Cardiac Surgery. Kidney Int. 76, 885-892. DOI: 10.1038/ki.2009.270.

17. Schwartz GJ, Furth SL. 2007. Glomerular Filtration Rate Measurement and Estimation in Chronic Kidney Disease. Pediatr Nephrol. 22(11),1839-1948.

18. Jenkins KJ, Gauvreau K, Newburger JW, et al. 2002. Consensus-Based Method for Risk Adjustment for Surgery for Congenital Heart Disease. J Thorac Cardiovasc Surg.123(1), 110-118.

19. Blinder JJ, Goldstein SL, Lee VV, et al. 2012. Congenital Heart Surgery in Infants: Effects of Acute Kidney Injury on Outcomes. J Thorac Cardiovasc Surg. 143, 368374. DOI: $10.1016 /$ j.jtcvs.2011.06.021.

20. Garcia RU, Walters HL, Delius RE, et al. 2016. Acute Kidney Injury Following First-stage Palliation in Hypoplastic Left Heart Syndrome: Hybrid Versus Norwood Palliation. Pediatr Cardiol. 37, 271. DOI:10.1017/S1047951117001809.

21. Rosner MH, Okusa MD. 2006. Acute Kidney Injury Associated with Cardiac Surgery. Clin J Am Soc Nephrol. 1(1), 19-32.

22. Chertow GM, Lazarus JM, Christiansen CL, et al. 1997. Preoperative Renal Risk Stratification. Circulation. 95, 878-884.

23. Mehta RL, Kellum JA, Shah SV. et al. 2007. Acute Kidney Injury Network: Report of an Initiative to Improve Outcomes in Acute Kidney Injury. Crit Care. 11, R31.

24. Selewski DT, Cornell TT, Heung M, et al. 2014. Validation of the KDIGO Acute Kidney Injury Criteria in a Pediatric Critical Care population. Intensive Care Med. 40, 1481-1488.

25. Haase M, Bellomo R, Haase-Fielitz A. 2010. Novel Biomarkers, Oxidative Stress, and the Role of Labile Iron Toxicity in Cardiopulmonary Bypass-Associated Acute Kidney Injury. J Am Coll Cardiol. 55, 2024-2033. DOI:10.1016/j.jacc.2009.12.046.

26. Lu JC, Coca SG, Patel UD, et al. 2009.Translational Research Investigating Biomarkers and Endpoints for Acute Kidney Injury (TRIBE-AKI) Consortium: Searching for Genes that Matter in Acute Kidney Injury: A Systematic Review. Clin J Am Soc Nephrol. 4, 1020-1031. DOI: 10.2215/CJN.05411008. 
27. Parikh CR, Devarajan P, Zappitelli M, et al. 2011. Postoperative Biomarkers Predict Acute Kidney Injury and Poor Outcomes after Pediatric Cardiac Surgery. J Am Soc Nephrol. 22(9), 1737-1747. DOI: 10.1681/ASN.2010111163.

28. Sindhvananda W, Phisaiphun K, Prapongsena P. 2013. No Renal Protection from Volatile Anesthetic Preconditioning in Open Heart Surgery. J Anesth. 27, 48-55. DOI: $10.1007 / \mathrm{s} 00540-012-1461-\mathrm{z}$.

29. Fukazawa K, Lee HT. 2014. Volatile Anesthetics and AKI: Risks, Mechanisms, and a Potential Therapeutic Window. J Am Soc Nephrol. 25, 884-892.

30. Yoo YC, Shim JK, Song Y, et al. 2014. Anesthetics Influence the Incidence of Acute Kidney Injury Following Valvular Heart Surgery. Kidney Int. 86, 414-22. DOI: $10.1038 /$ ki.2013.532.

31. Wiedemann HP, Wheeler AP, Bernard GR, et al. 2006. Comparison of Two FluidManagement Strategies in Acute Lung Injury. $N$ Engl J Med. 354, 2564-2575. DOI: 10.1056/NEJMoa062200

32. Bagshaw SM, Brophy PD, Cruz D, et al. 2008. Fluid Balance as a Biomarker: Impact of Fluid Overload on Outcome in Critically Ill Patients with Acute Kidney Injury. Crit Care. 12, 169. DOI: 10.1186/cc6948.

33. Macedo E, Bouchard J, Soroko SH, et al. 2010. Fluid Accumulation, Recognition and Staging of Acute Kidney Injury in Critically-Ill Patients. Crit Care. 14(3), R82. DOI: $10.1186 /$ cc9004.

34. Hazle MA, Gajarski RJ, Yu S, et al. 2013. Fluid Overload in Infants Following Congenital Heart Surgery. Pediatr Crit Care Med. 14, 44-49. DOI: 10.1097/PCC.0b013e3182712799.

35. Hirleman E, Larson DF. 2008. Cardiopulmonary Bypass and Oedema: Physiology and Pathophysiology. Perfusion. 23, 311-322. DOI: 10.1177/0267659109105079.

36. Smit M, Hofker HS, Leuvenink HG, et al. 2013. A Human Model of Intraabdominal Hypertension: Even Slightly Elevated Pressures Lead to Increased Acute Systemic Inflammation and Signs of Acute Kidney Injury. Crit Care. 17, 425. DOI: $10.1186 / \mathrm{cc} 12568$.

37. Wauters J, Claus P, Brosens N, et al. 2009. Pathophysiology of Renal Hemodynamics and Renal Cortical Microcirculation in a Porcine Model of Elevated Intra-Abdominal Pressure. J Trauma. 66, 713-719. DOI: 10.1097/TA.0b013e31817c5594.

38. Pedersen KR, Hjortdal VE, Christensen S, et al. 2008. Clinical Outcome in Children with Acute Renal Failure Treated with Peritoneal Dialysis After Surgery for Congenital Heart Disease. Kidney Int Suppl. S81-86. DOI: 10.1038/sj.ki.5002607.

39. Sorof JM, Stromberg D, Brewer ED, et al. 1999. Early Initiation of Peritoneal Dialysis after Surgical Repair of Congenital Heart Disease. Pediatr Nephrol. 13, 641-645. 
40. Hassinger AB, Wald EL, Goodman DM. 2014. Early Postoperative Fluid Overload Precedes Acute Kidney Injury and is Associated with Higher Morbidity in Pediatric Cardiac Surgery Patients. Pediatr Crit Care Med. 15, 131-138. DOI: 10.1097/PCC.0000000000000043.

41. Lehman LW, Saeed M, Moody G, et al. 2010. Hypotension as a Risk Factor for Acute Kidney Injury in ICU Patients. Comput Cardiol. 37, 1095-1098. PMID: 22158679.

42. Kanji HD, Schulze CJ, Hervas-Malo M, et al. 2010. Difference between PreOperative and Cardiopulmonary Bypass Mean Arterial Pressure is Independently Associated with Early Cardiac Surgery-Associated Acute Kidney Injury. J Cardiothorac Surg. 5, 71. DOI: 10.1186/1749-8090-5-71.

43. Bennett M, Dent C, Ma Q, et al. 2008. Urine NGAL Predicts Severity of Acute Kidney Injury After Cardiac Surgery: A Prospective Study. Clin J Am Soc Nephrol. $3,665-673$.

44. Alshaikh HN, Katz NM, Gani F, et al. 2018. Financial Impact of Acute Kidney Injury After Cardiac Operations in the United States. Ann Thorac Surg. 105(2), 469-475. DOI 10.1016/j.athoracsur.2017.10.053. Epub 2017 Dec 21. 


\section{LIST OF PUBLISHED ARTICLES AND ABSTRACTS}

\section{Published articles}

1. J. Krastins, Z. Straume, J. Auzins, A. Petersons, A. Petersons. Incidence and outcome of acute kidney injury after open heart surgery in children. Acta Krastins, J. 2014. Acute kidney injury - an underestimated problem in pediatric intensive care. Proceedings of the Latvian Academy of Sciences. V68, 207-216.

2. Krastins, J., Auzins, J., Straume, Z., Petersons, A., Amerika, D., Petersons, A., Erts, R. 2014. Urinary Neutrophil Gelatinase Associated Lipocalin Predicts Open Heart Surgery Related Acute Kidney Injury in Children. Proceedings of the Latvian Academy of Sciences. V68, A5-A6.

3. Krastins, J., Straume, Z., Auzins, J., Petersons, A., Petersons, A. 2012. Incidence and outcome of acute kidney injury after open heart surgery in children. Acta Medica Lithuanica. 19, 237-243.

4. Krastins, J., Straume, Z., Auzins, J., Petersons, A., Amerika, D., Petersons, A. 2013. Open hear surgery associated acute kidney injury in children. Acta Chirurgica Latviensis. (13/1), 37-41.

5. Krastyn'sh, E., Straume, Z., Auzyn'sh, I., Petersons, A., Petersons, A. 2014. Acute renal failure after cardiopulmonary bypass surgery in children with congenital heart disease. Vestn Khir Im I I Grek. 173(4), 78-82. PMID: 25552112.

6. Krastin, J. V., Majors, I. K., Graudums, B. A., Iaksona, B. V., Vamvuri, L. A. 1979. Transcutaneous catheterization of the vena cava superior through the internal jugular vein in children. Vestn Khir Im I I Grek. 122(5), 101-104. PMID: 452257.

7. Krastins, J. 2015. AKI - an Underestimated Problem in the Pediatric Intensive Care. Lambert Academic Publishing. 84. ISBN-10; 3659688509.

8. Krastiņš, J., Pētersons, A. Patents LV 15070 B "Nieru funkciju atjaunošanās iespēju noteikšanas pan̄ēmiens 24 stundu laikā bērniem pēc kardioķirurǵiskām operācijām.” Published 20.04.2016. 


\section{Abstracts}

1. Krastins, J., Straume, Z., Auzins, J. 2012. Perioperative Changes in Renal Biomarkers in Children Undergoing Open Heart Surgery. Arch Dis Child. 97, A471-A472.

2. Krastins, J. Straume, Z., Auzins, J. Perioperative Dynamics of Glomerular Filtration Rate in Children Undergoing Open Heart Surgery. RSU 2012. gada zinātniskā konference (Rīgā, 2012. gada 29.-30. martā).Tēzes, 235.

3. Krastins, J., Straume, Z., Auzins, J. 2012. Perioperative Dynamics of Creatinine Clearance in Children with Congenital Heart Disease. 12 ${ }^{\text {th }}$ Conference of the Baltic Association of Pediatric Surgeons, 17-19 May, Riga, Latvia. Final program and abstracts, 106.

4. Krastins, J., Straume, Z., Auzins, J. 2012. Evaluation of Cystatin C as a biomarker of kidney injury in children. Acta Medica Lithuanica. 19, 365.

5. Krastins, J., Straume, Z., Auzins, J., Petersons, A., Petersons, A. Open heart associated renal dysfunction in children. 2013. gada RSU zinātniskā konference (Rīgā, 2013. gada 14.-15. aprīilì). Tēzes, 237.

6. Krastins, J., Straume, Z., Auzins, J., Petersons, A., Petersons, A. Open heart surgery associated renal dysfunction in children. $2^{\text {nd }}$ Baltic Pediatric Congress, Pärnu 2013. Abstracts, 52.

7. Krastins, J., Straume, Z., Auzins, J., Petersons, A., Amerika, D., Petersons, A. Evaluation of Neutrophil Gelatinase-Associated Lipocalin as a marker of open heart surgery related acute kidney injury in children. RSU 2014. gada zinātniskā konference (Rīgā, 2014. gada 10.-11. aprīīī). Tēzes, 250.

8. Krastins, J., Auzins, J., Petersons, A., Petersons, A. 2014. Incidence of pediatric open heart surgery related acute kidney injury, its severity and outcome. Pediatr Crit Care Med. Vol. 15 (4), Abstract No 536.

9. Krastins, J., Auzins, J., Petersons, A., Amerika, D., Petersons, A., Erts, R. 2014. Neutrophyl Gelatinase-Associated Lipocalin as a Marker of Open Heart Surgery Related Acute Kidney Injury in Children. Pediatric Nephrology. V29, 1844.

10. Krastins, J. Acute kidney injury - an underestimated problem in the pediatric intensive care. Abstracts $3^{\text {rd }}$ Baltic Pediatric Congress, 19-21 August 2015, Riga, Latvia. 1-84.

11. Krastins, J., Mahlina, K., Birznieks, M., Gravele, D., Amerika, D., Petersons, A., Petersons, A., Erts, R. Evaluation of Kidney Injury Markers in Children, Undergoing Open Heart Surgery. RSU 2016. gada zinātniskā konference (Rīgā, 2016. gada 16.-17. martā). Tēzes, 174. 


\section{Public presentations}

1. LARA 5. Nacionālais kongress (Liepājā, 2011. gada 9.-10. decembrī).

2. RSU 2011. gada zinātniskā konference (Rīgā, 2011. gada 14.-15. aprīīi).

3. $6^{\text {th }}$ International Baltic Congress of Anaesthesiology and Intensive Care, 18-20 October 2012. Vilnius, Lithuania.

4. RSU 2012. gada zinātniskā konference (Rīgā, 2012. gada 29.-30. martā).

5. RSU 2013. gada zinātniskā konference (Rīgā, 2013. gada 14.-15. aprīlī).

6. $2^{\text {nd }}$ Baltic Paediatric Congress Pärnu, Estonia (30 May-1 June 2013).

7. $24^{\text {th }}$ Annual ESPNIC congress Rotterdam, Netherlands (12-15 June 2013).

8. RSU 2014. gada zinātniskā konference (Rīgā, 2014. gada 10.-11. aprīīî).

9. $7^{\text {th }}$ International Baltic Congress of Anesthesiology (Riga, 4-6 December 2014).

10. $7^{\text {th }}$ World Congress on Pediatric Intensive and Critical Care, Istambul (4-7 May 2014).

11. $47^{\text {th }}$ Annual Scientific Meeting of the European Society for Pediatric Nephrology, Porto (18-20 September 2014).

12. RSU 2015. gada zinātniskā konference (Rīgā, 2015. gada 26.-27. martā).

13. $26^{\text {th }}$ Annual ESPNIC Congress Vilnius Lithuania (10-13 June 2015).

14. $3^{\text {rd }}$ Baltic Paediatric Congress in Riga, Latvia (19-21 August 2015).

15. RSU 2016. gada zinātniskā konference (Rīgā, 2016. gada 16.-17. martā).

16. $8^{\text {th }}$ International Baltic Congress of Anesthesiology and Intensive Care, Tallinn, Estonia (1-3 December 2016).

17. $28^{\text {th }}$ Annual ESPNIC Congress Lisbon Portugal (6-9 June 2017).

18. LARA 6. Nacionālais kongress (Ventspilī, 2017. gada 8.-9. decembrī).

\section{Summary}

\begin{tabular}{|l|c|}
\hline \multicolumn{1}{|c|}{ Activity } & Qty. \\
\hline Oral presentation in International Congress & 5 \\
\hline Oral presentation in National Congress & 2 \\
\hline Oral presentation in local conference & 5 \\
\hline Article published in journal, listed in LCS & 4 \\
\hline Article published in peer-reviewed journal & 2 \\
\hline Abstract published in peer rewieved journal & 6 \\
\hline Abstract published in the Proceedings & 4 \\
\hline Published Monograph & 1 \\
\hline
\end{tabular}




\section{ACKNOWLEDGEMENTS}

I want to thank my supervisors Professors Aigars Pētersons and Aivars

Pētersons for interest and support in my research. They relentlessly, but kindly, helped me to push ahead with this work and their experience and assistance in practical matters have been most helpful.

I am deeply grateful to Renārs Erts for his assistance in the statistical analysis of data.

I am also indebted to Professor Rafails Rozentāls, doctors Dagne Grāvele and Diāna Amerika, their contribution was of utmost importance especially for the sample processing in the laboratory.

I express my warmest gratitude to Professor Biruta Mamaja, my first mentor in the field of pediatric cardiac anesthesia.

I would like to thank Irena Rogovska for her guidance to research and comments to advance my study.

I am lucky to be a member of very competent and inspiring team of doctors, in the Clinics of Anethesiology and Intensive Care and Clinics of Pediatric Cardiology and Cardiac Surgery whose support and co-operation have made it possible to carry out this work. I am also grateful to the nurses and nurse assistants in ICU, they have diligently carried out all requests regardless of the hectic workload of their own. 